\title{
Pedagoogilisel praktikal ja kutseaastal osalejate kogemused blogipostituste põhjal
}

\author{
Piret Luik $^{\mathrm{a} 1}$, Merle Taimalu ${ }^{\mathrm{a}}$ \\ a Tartu Ülikooli haridusteaduste instituut
}

\begin{abstract}
Annotatsioon
Õpetajakoolitus on viimastel aastatel olnud Eestis suure tähelepanu all. Pedagoogiline praktika ja kutseaasta kui õpetajakoolituse esimesed etapid avaldavad väga suurt mõju üliõpilase isiklikule ja professionaalsele arengule. Seepärast on oluline uurida, mida üliõpilased kogevad oma esmasel kokkupuutel õpetaja elukutsega. Üht võimalust selleks pakuvad hariduslikud blogid, milles käsitletavad teemad võimaldavad jälgida praktikantide ja algajate õpetajate õppimis- ja mõtlemisprotsessi. Uurimuse eesmärk on välja selgitada, millest ja kuidas kirjutavad blogis õpetajakoolituse üliõpilased pedagoogilisel praktikal ja algajad õpetajad kutseaastal. 2010/11. ja 2012/13. õppeaastal korraldatud uuringus osales 243 blogijat. Andmeid koguti blogist, mida õppijad kasutasid praktika või kutseaasta jooksul vabatahtlikult omavaheliseks suhtluseks. Artiklis analüüsitakse saadud tulemusi kvantitatiivselt ning antakse nende põhjal soovitusi pedagoogilise praktika ja kutseaasta korraldajatele.
\end{abstract}

Võtmesõnad: pedagoogiline praktika, kutseaasta, blogi, õpetaja professionaalne areng

\section{Sissejuhatus}

Õpetajakoolituse alla kuulub nii õpetajate esmaõpe, sellele järgnev kutseaasta kui ka õpetajate professionaalset arengut toetav täiendusõpe (Eisenschmidt, 2006a). Õpetajate esmaõppe üks kõige olulisem osa on pedagoogiline praktika (edaspidi: praktika), kus õpetajaks pürgija saab esmase reaalse õpetamiskogemuse ja nii mõnigi kord peab korrigeerima oma esialgseid ettekujutusi õpetamisest ja õpetajatööst (Sinclair, Dowson, \& McInerney, 2006). Erinevalt praktikal osalejast vastutab kutseaastal olev

1 Haridusteaduste instituut, Tartu Ülikool, Salme 1a, 50103 Tartu; piret.luik@ut.ee 
algaja õpetaja (edaspidi: algaja õpetaja) juba täielikult oma töö eest, sealhulgas õpilaste arengu toetamise ja heaolu tagamise eest. Praktika kohta võib esile tuua nii positiivset kui ka negatiivset: ühelt poolt kogevad õppijad põnevust esmakordse õpetamiskogemuse saamisel ja teiselt poolt võivad nad kahelda oma oskustes, kuidas nad saavad hakkama uues olukorras, suheldes õpilaste, mentori ja juhendajaga (Perry, 2004, viidatud Kiggundu \& Nayimuli, 2009 järgi). Sama võib öelda ka kutseaasta kohta.

Õpetamist on peetud ka n-ö isoleeritud elukutseks (Graham, 1997, viidatud Merrill, 2006 järgi), sest sageli jääb tunnis toimuv klassiruumi seinte vahele ja õpetajad ei kipu omavahel kogemusi jagama. Algajad õpetajad vajavad aga siiski võimalust jagada oma kogemusi, rõõme ja muresid kutseaastal - ja seda nii oma mentoriga kui ka teiste samas etapis olevate, kutseaastat läbivate õpetajatega (Merrill, 2006). Õpetajate professionaalse arengu toetamiseks on oluline, et nad moodustaksid omavahel meeskondi (Vavasseur \& MacGregor, 2008) ja jagaksid üksteisega kogemusi ning otsiksid lahendusi tekkinud probleemidele. Peale näost näkku kohtumiste pakuvad selliseks suhtluseks lisavõimalusi ka blogid. Blogisid on hakatud üha enam kasutama hariduses, sh õpetajakoolituses. Neid saab kasutada eri moel ja eri eesmärkidel, näiteks igapäevaelu dokumenteerimiseks, emotsioonide väljendamiseks, teistega suhtlemiseks, õppimiseks, õppeülesannete andmiseks ja hindamiseks (Sim \& Hew, 2010). Blogimine hariduslikel eesmärkidel võib olla kas vabatahtlik või kohustuslik ning autorid on selles eri seisukohtadel. Näiteks peavad Deng ja Yuen (2013) blogimise vabatahtlikkust blogimisaktiivsust takistavaks teguriks, kuid Can ja Ozdemir (2006) arvavad vastupidist. Tänapäeval rõhutatakse ka vajadust luua õpetajakoolituse tarbeks õppivaid kogukondi (Vescio, Ross, \& Adams, 2008), milleks pakuvad häid võimalusi kollektiivsed blogid, kus saavad korraga osaleda ja teemasid või arutelusid algatada paljud õppijad (Agarwal, Liu, Tang, \& Yu, 2012). Esile on toodud ka katarsise efekti, mis avaldub selles, et blogisse kirjutamine võimaldab osalejatel mingi kogemuse või probleemi endast välja kirjutada (Fisher \& Kim, 2013). Blogipostitused võimaldavad teha õppimise ka nähtavamaks (ibid.). Seega annab blogi võimaluse uurida, millistest kogemustest kirjutatakse õpetajakoolituses, ning praktikat ja kutseaastat edasi arendada.

Järgnevalt antakse ülevaade varasematest uurimustest kutseaastal ja praktikal kogetu kohta. Andmeid on kogutud nii tavapäraselt ankeetide ja intervjuude kaudu kui ka blogide ja teiste elektroonsete vahendite abil. 


\section{Aktuaalsed teemad praktika ja kutseaasta ajal}

Kõige sagedasemad teemad, mis kerkivad esile peaaegu kõigis praktikaga seotud uurimustes, puudutavad õpetamist/õpetajat (nt õpetamismeetodite rakendamine, ainealane ettevalmistus), klassi juhtimist (classroom management) ning distsipliini, õpilaste käitumisega ja raskete õpilastega hakkamasaamist (Fisher \& Kim, 2013; Kiggundu \& Nayimuli, 2009; Mapfumo, Chitsiko, \& Chireshe, 2012; Marais \& Meier, 2004; Mariko, 2011; Ozdemir \& Yildirim, 2012; Rettig, 2013). Näiteks ilmneb Rettigi (2013) uurimusest, et $34 \%$ postitustest on seotud praktikaaegse õpetamise ja klassi juhtimise teemaga, samuti on algajad õpetajad toonud kõige suurema probleemina välja klassi juhtimise (Eisenschmidt, 2006b; Haggarty, Postlethwaite, Diment, \& Ellins, 2011; Poom-Valickis, 2007). Õpetajaks olemise teema on kutseaastat läbivate õpetajate jaoks oluline: algajad õpetajad mõtlevad endast kui „professionaalsest minast” ning valitud töö väärtusest ja enda proovilepanekust (Findlay, 2006), planeerimisest, õppeprotsessi juhtimisest ja professionaalsest arengust (Poom-Valickis, 2007, 2014), õppekava rakendamisest ja endast kui õpetajast (Eisenschmidt, 2006b).

Peale eelnimetatud teemade on uurimustes välja toodud ka ópilaste teema. Õpilastega seonduvat (nt õppimisvajadusi ja õpilaste käitumist) on käsitletud praktika kohta tehtud uurimustes (Mariko, 2011), kuid sama teema pakub ootuspäraselt huvi ka kutseaastal osalejatele (Eisenschmidt, 2006b; Haggarty et al., 2011; Poom-Valickis, 2007). Võttes kokku õpetamise ja õpilastega seotud teemad, paigutus ühes praktikaaegsete blogipostituste uurimuses $47 \%$ postitustest nende kahe teema alla (Rettig, 2013).

Eraldi teemarühmana võib esile tuua praktika korralduse teema, mis hõlmab mentori ja/või juhendaja tegevust (nt Mapfumo et al., 2012; Ozdemir \& Yildirim, 2012), samuti praktikakoha (kooli) ettevalmistatuse taseme teema (nt Kiggundu \& Nayimuli, 2009; Ozdemir \& Yildirim, 2012; Rettig, 2013), mis on olnud praktikantide blogide põhjal teemadest kõige levinum (Luik, Voltri, Taimalu, \& Kalk, 2011). Uurimustes on muredena välja toodud probleemid ülikoolipoolsete juhendajate ja koolipoolsete mentoritega. Näiteks on kurdetud, et praktikanti eriti ei juhendatud, vaid teda võeti kui asendusõpetajat, kes andis päris õpetajale võimaluse puhata, või olid juhendajad lausa ebakompetentsed (Ozdemir \& Yildirim, 2012). Puudusena on nimetatud ka seda, et koolid polnud praktikantide tulekuks piisavalt valmistunud (Kiggundu \& Nayimuli, 2009; Marais \& Meier, 2004; Mukeredzi \& Mandrona, 2013; Ozdemir \& Yildirim, 2012) või praktikante ei tutvustatud teistele õpetajatele/koolitöötajatele ega respekteeritud teiste poolt. Samuti on osutatud koolikeskkonna puudujääkidele, mis ei 
võimaldanud ülikoolis õpitut rakendada (Kiggundu \& Nayimuli, 2009; Ozdemir \& Yildirim, 2012), näiteks õpetamise ja õppimise jaoks vajalike abivahendite (nt õpikute) nappus (Mapfumo et al., 2012). Vastukaaluks on juhendajatega seoses toodud uurimustes välja ka positiivseid aspekte, milleks on emotsionaalne toetus, eeskujuks olek ja tehniline tugi (Caires, Almeida, \& Vieira, 2012; Marais \& Meier, 2004). Juhendamise ja mentoritelt toetuse saamise teema on aktuaalne ka kutseaastal, näiteks tagasiside mentorilt ja toetuse saamine nii mentorilt kui ka kolleegidelt või kaaslastelt (Eisenschmidt, 2006b; Findlay, 2006; Fry, 2007; Poom-Valickis, 2007).

Esmakordne kokkupuude reaalse õpetamisega toob loomulikult kaasa lisakohustusi ja kohanemisprobleeme. Neidki teemasid kohtab varasemates uurimustes. Suurtele nõudmistele ja kasvanud töökoormusele praktika ajal osutavad Mapfumo jt (2012) ning Cairesi jt (2012) tulemused, sedasama on täheldanud kutseaasta kohta Findlay (2006) ja Fry (2007). Institutsionaalse ja isikliku kohanemise teema, mille korral tekitas probleeme üleminek üliõpilase rollilt õpetaja rollile, kohanemine kooli nõudmistega ja suhted teiste õpetajatega, ilmnes samuti nii praktika kui ka kutseaasta puhul (Eisenschmidt, 2006b; Poom-Valickis, 2007).

Inimestevahelised suhted (suhted opetajate, direktori, juhendajate, lapsevanematega) on välja toodud Ben-Peretzi ja Kupferbergi (2007) uurimuses, kus see oli üks sagedasem teema, millest autorid järeldasid, et see vajaks õpetajate ettevalmistuses rohkem tähelepanu. Suhted lapsevanematega on võrdlemisi harva esinev teema, mida enamik uurimusi esile ei too. Rettigi (2013) uurimuse järgi tehti sellel teemal kõige vähem postitusi, peamiselt oli juttu õpetaja-lapsevanema kohtumistest (arenguvestlused), ning selle teema kohta esitati nii positiivseid kui ka negatiivseid kommentaare ja küsiti küsimusi. Lapsevanemate ootuste teemat on nimetatud ka Eisenschmidti (2006b) uurimuses, kus algajad õpetajad toovad esile mure oma kogenematuse pärast.

Ülejäänud teemasid käsitletakse blogides harvem ja neid on mainitud vaid üksikutes uurimustes, näiteks üldine informatsioon praktika kohta (Rettig, 2013), majanduslikud raskused (Mapfumo et al., 2012), emotsioonid õpetajatöös, sh õpilaste reaktsioonidest tulenevad või tulevikule orienteeritud emotsioonid (Poulou, 2007). Blogides, millega toetati inglise keele õpetajaks õppijate professionaalset arengut, ilmnesid kaks lisateemat: õppimine teistelt professionaalidelt ja enda professionaalne areng. Postitustes mainitud probleemid olid seotud mõne raske klassisituatsiooniga ja õpetamisarusaamade ühitamisega (Fisher \& Kim, 2013). Huvitavana on Marais' ja Meieri (2004) uurimuses esile toodud ka teooria ja praktika kooskõla teema, seda nii positiivse kui ka negatiivse poole pealt. 


\section{Praktika ja kutseaastaga seotud mured ja rõõmud}

Peaaegu kõigis praktikat käsitlevates uurimustes on nimetatud praktika jooksul esilekerkivaid muresid ja probleeme (ainult muresid on uurinud nt Mapfumo et al., 2012; Poulou, 2007). Samas on mitmed autorid osutanud ka positiivsetele aspektidele ja edulugudele (nt Caires et al., 2012; Kiggundu \& Nayimuli, 2009; Marais \& Meier, 2004; Mukeredzi \& Mandrona, 2013; Rettig, 2013; Sivan \& Chan, 2003).

Mitme teema puhul on esindatud mõlemad pooled, st mured ja rõõmud. Näiteks käsitletakse praktika/kutseaasta juhendamise ja mentorlusega seoses nii muresid (nt Ozdemir \& Yildirim, 2012) kui ka rahulolu (nt Caires et al., 2012; Eisenschmidt, 2006c; Marais \& Meier, 2004). Niisamuti väljendatakse õpetajaks olemise ja õpetamisega seoses muret (nt Rettig, 2013), kuid tuntakse ka rõõmu kasvanud teadmistest, oskustest ja enesetõhususest (Caires et al., 2012; Poom-Valickis, 2014). Teemad, mille puhul nimetati uurimustes vaid muresid, olid klassi juhtimine, distsipliin ja probleemsete õpilastega toimetulek (Eisenschmidt, 2006c; Haggarty et al., 2011; PoomValickis, 2007; Rettig, 2013), suurenenud nõudmised ning töökoormus nii praktika kui ka kutseaasta ajal (Caires et al., 2012; Findlay, 2006; Fry, 2007; Mapfumo et al., 2012). Positiivsena on nimetatud ka suhteid kolleegidega (Eisenschmidt, 2006c; Mukeredzi \& Mandrona, 2013).

Kuigi enamikus uurimustes on rõhk asetatud murede ja probleemide esiletoomisele, leidub ka vastupidiseid näiteid. Rettig (2013) osutab, et üldiselt olid postitused oma laadilt positiivsed, negatiivseid postitusi oli väga vähe. Üliõpilased kasutasid foorumit praktikal saadud kogemuste jagamiseks ja nende üle reflekteerimiseks. Selles uurimuses ilmnesid mõningad suundumused, mis olid seotud postituse tegemise ajaga (andmeid koguti kaheksa semestri jooksul). Nimelt tehti iga semestri alguses enamik postitusi üldiselt klassi ja kooli ning praktikantidelt nõutud projektide kohta. Semestri lõpu poole ilmusid blogidesse postitused, milles käsitleti (õpingute) lõpetamist, tööd ja tööintervjuusid ning praktikakohast lahkumisega kaasnevat kurbust (Rettig, 2013). Positiivsema poole pealt on ülalpool öeldule lisaks esile toodud teemasid, mis puudutavad teadmiste ja oskuste ning enesetõhususe ja paindlikkuse kasvu oma tegevuses õpetajana (Caires et al., 2012; Poom-Valickis, 2014), mõnes uurimuses on rõhutatud ka praktika ja kutseaasta juhendamise / mentori tegevuse head kvaliteeti (Caires et al., 2012; Eisenschmidt, 2006c; Marais \& Meier, 2004). 


\section{Õpetaja professionaalne areng praktika ja kutseaasta jooksul murede mudeli põhjal}

Õpetaja professionaalse arengu kohta on välja pakutud eri teooriaid, millest enamik hõlmab astmelisi mudeleid (nt Berlineri õpetaja kompetentsusastmete teooria, vt Barone, Berliner, Blanchard, Casanova, \& McGowan, 1996), ja nende kõigi puhul võib esile tuua ühe ühisjoone - astmed on kindlalt määratletud ja mudelid on üles ehitatud hierarhiliselt alates madalama taseme oskustest kuni kõrgema taseme oskusteni (Dall'Alba \& Sandberg, 2006). Õpetaja professionaalses arengus on laialdast kasutust leidnud klassikalised, nn murede mudelid, millest esimene oli Fulleri kolmeastmeline mudel, mille alusel eristati iseenda, õpetamise ja õpilaste õpitulemustega seonduvaid muresid (Fuller, 1969, Eisenschmidt, 2006b järgi). Hilisemad uurijad on seda mudelit mitmel moel täiendanud, muutes mudeli näiteks neljaastmeliseks (Fuller \& Bown, 1975). Samuti on loodud kaheksaastmeline mudel, kus peale murede käsitletakse ka õpetaja ootusi (Conway \& Clark, 2003). Conway ja Clark (2003) osutavad, et murede mudel sobib ka õpetajakoolituse üliõpilaste jaoks. Siinne artikkel põhinebki Fulleri ja Bowni murede teoorial ja seetõttu tutvustatakse seda alljärgnevalt lähemalt. Kõnealune mudel osutus sobivaks, sest selle igas staadiumis kirjeldatakse algaja õpetaja muresid ning teemasid, millega mured peamiselt seostuvad.

Tulevase/algaja õpetaja professionaalne areng algab esimesel astmel illusioonidega õpetajatööst ja kulgeb läbi enesekesksete staadiumite järjest õpilasekesksema poole. Eestis tehtud töödes on neid staadiumeid mõneti erinevalt nimetatud. Õim (2008) nimetab esimest staadiumit fantaasiaillusioonide staadiumiks, Eisenschmidt (2006a) fantaasiastaadiumiks (illusioon). See staadium on tavapärane nende üliõpilaste jaoks, kes pole veel praktikal olnud. Ettekujutus õpetajatööst on sageli ebareaalne, põhineb illusioonidel ja enda kogemusel õpilasena. Ennast nähaksegi õpilase, mitte veel õpetajana. Esimese vaatluspraktika käigus võivad üliõpilased olla vaadeldava õpetaja tegevuse suhtes väga kriitilised, kuna ennast samastatakse õpilasega ja pole veel üle mindud n-ö vaenlase poolele (Fuller \& Bown, 1975). Üliõpilased läbivad illusioonide staadiumi suhteliselt kiiresti ja see on omane just praktikal olijatele, kellel varasemat isiklikku õpetajatöö kogemust pole. Seejärel liiguvad üliõpilased edasi teise staadiumisse, mida nimetatakse ellujäämise (Õim, 2008) või püsimajäämise staadiumiks (Eisenschmidt, 2006a). Esimesed praktikakogemused võivad kaasa tuua šoki ja arusaamise, et õpitust jääb väheks. Illusioonid purunevad ja senised arusaamad on vaja ümber hinnata, sest mõistetakse, kui keeruline ja palju 
nõudev on õpetajatöö. Algaja õpetaja või praktikant muretsebki eelkõige enesekeskselt oma toimetuleku ja ellujäämise pärast. Näiteks valmistab talle muret, kas ta suudab klassis distsipliini hoida, kui pädev on ta ainealaselt, milliseks kujunevad suhted juhendaja ja kolleegidega. Põhitähelepanu lähebki distsipliinile ja klassi juhtimisega kaasnevatele probleemidele. See etapp on seotud esimeste reaalsete õpetamiskogemustega (praktika, kutseaasta algusetapp) ja on enamasti suure stressi periood (Fuller \& Bown, 1975). Tänu läbitud praktikale peaksid kutseaastal olevad algajad õpetajad algusest peale omama realistlikku ettekujutust õpetajatööst ja seetõttu võiks oletada, et nad alustavad kohe teisest, ellujäämise staadiumist ning illusioonide staadiumit neil enam ei esine. Umbes poole aasta pärast või varem (kui klassi juhtimisega saadakse juba hakkama) jõuab enamik õpetajaid kolmandasse ehk õpetamise (Õim, 2008) või meisterlikkuse staadiumisse (Eisenschmidt, 2006a). Muretsetakse peamiselt oma õpetamistegevuse ja -oskuste pärast (nt kuidas suudetakse ainekava sisu edasi anda või mõnd teemat/mõistet kõige paremini õpetada, mis meetod sobib õpetamiseks kõige paremini). Püütakse üles leida varasemate õpingute konspektid ja tuletada meelde kursustel tehtu-soovitatu (Fuller \& Bown, 1975). Lõpuks jõutakse neljandasse, viimasesse staadiumisse, mida võib nimetada õpetamise mõju tajumise (Õim, 2008) või toimetuleku/edu staadiumiks (Eisenschmidt, 2006a). Siin suunatakse tähelepanu endast üha rohkem väljapoole, st õppija poole. Hakatakse nägema õpilase vajadusi ja muretsema selle pärast, kuidas suudetakse jõuda kõigi õpilasteni, soodustada nende õppimist ja arvestada nende vajadustega (Fuller \& Bown, 1975). On üsna tõenäoline, et suhteliselt lühikest aega toimuva õpetamispraktika jooksul ei jõua õpetajakoolituse üliõpilased veel viimasesse, aga võib-olla ka mitte eelviimasesse (õpetamise) staadiumisse. Seevastu kutseaastal olijatelt võiks loota, et ellujäämise staadium läbitakse kiiresti ning peamisteks staadiumiteks on õpetamise ja õpetamise mõju tajumise staadium.

Eisenschmidt (2006b) on oma doktoritöös „Kutseaasta kui algaja õpetaja toetusprogrammi rakendamine Eestis" esile toonud, et mured on õpetaja arengus olulisel kohal ja muredel põhinevat õpetaja professionaalse arengu käsitlust võib nimetada ka „... enesekontseptsiooni kujunemist analüüsivaks mudeliks, kus kasvab õpetaja teadlik suhtumine oma elukutsesse, ilmnevad konkreetse õpetaja arusaamad oma professioonikäsitusest, aga kindlasti ka ühiskondlikud tendentsid" (lk 31). Poom-Valickis, kes on uurinud selliseid Eesti kutseaastaga seonduvaid teemasid nagu õppetöö planeerimine algaja õpetaja poolt, õppeprotsessi juhtimine ja koostöö ning professionaalne areng ja enesetõhusus, on leidnud, et kõigi näitajate puhul paranesid algajate õpetajate hinnangud kutseaasta jooksul. Üllatav 
oli tulemus, et algajad õpetajad muutusid kutseaasta lõpuks oluliselt autoritaarsemaks, püüdes distsipliiniprobleemidega toimetulemiseks kasutada karistusi ja hirmutamist (Poom-Valickis, 2007, 2014).

Uurimustes, kus käsitletakse õpetajaks õppijate professionaalset arengut praktika jooksul, on leitud, et uuemad üliõpilased ei ole valmis praktikast täielikult kasu saama ega suuda tähendusrikkalt reflekteerida oma praktikakogemusi. Nad on eelkõige ellujäämise staadiumis: tunnevad survet ja ärevust, on mures töökoormuse ja tehniliste probleemide pärast ning kahtlevad endas. Kogenumad üliõpilased on need mured juba ületanud ning suudavad mõelda rohkem pedagoogiliste teemade peale ja sellele, mida kasulikku pakub praktika nende tulevase õpetajatöö jaoks ja kuidas õpilaste õppimist soodustada (Sivan \& Shan, 2003).

Eeltoodu põhjal võib öelda, et praktika avaldab suurt mõju üliõpilase isiklikule ja professionaalsele arengule ning sisaldab õpetajaks õppimise protsessi kogu rikkust ja keerulisust (Caires \& Almeida, 2005), sama kehtib ka kutseaasta kohta. Seetõttu tuleks uurida, millised on üliõpilaste kogemused esmasel kokkupuutel õpetaja elukutsega (hirmud, kahtlused, vajadused, ootused, edu, ebaedu). Siinse uurimuse eesmärk on välja selgitada, mis teemadel, täpsemalt mis muredest ja rõõmudest ning millisel professionaalse arengu astmel kirjutavad kollektiivses blogis õpetajakoolituse üliõpilased praktika ja algajad õpetajad kutseaasta jooksul. Sellest eesmärgist lähtudes püstitati kolm uurimisküsimust.

Varasemates uurimustes on toodud välja eri teemasid, millega õpetajakoolituse praktikandid ning kutseaastal osalevad algajad õpetajad kokku puutuvad. Tulemused on mõneti vasturääkivad. Näiteks osutavad Ben-Peretz ja Kupferberg (2007), et inimestevahelised suhted, sh suhted lapsevanematega, on üks levinuimaid teemasid, kuid Rettig (2013) väidab, et praktikandid mainivad seda teemat harva. Võimalik, et käsitletavad teemad olenevad praktika/kutseaasta perioodidest. Kuna praktika ja kutseaasta täidavad eri ülesandeid, siis on oluline teada, kuivõrd erinevad need teemad kahes õpetajakoolituse etapis. Seega kõlab esimene uurimisküsimus järgmiselt: mis teemadel kirjutasid praktikandid ja kutseaastal olevad algajad õpetajad praktika ja kutseaasta jooksul blogis ning kuidas muutusid need teemad praktika ja kutseaasta eri perioodidel?

Mitmetes uurimustes (nt Eisenschmidt, 2006c; Ozdemir \& Yildirim, 2012; Rettig, 2013) tuuakse välja, et üliõpilased kirjutavad ja räägivad nii muredest kui ka rõõmudest, kuid pole uuritud, kummaga puutuvad oma õpetajateed alustajad rohkem kokku ning kuivõrd see seostub praktika või kutseaasta eri perioodidega. Teades murede-rõõmude seost esilekerkivate teemadega, saab nendele teemadele õpetajakoolituses rohkem tähelepanu 
pöörata ja tulevaste õpetajate ettevalmistust tõhustada. Praktikal olijad saavad eri juhendajatelt rohkem toetust kui kutseaastal olijad, seepärast oleks oluline teada, kuivõrd erinevad kutseaasta ja praktika läbijate kirjutised murede ja rõõmude väljendamise poolest. Sellest lähtudes püstitati teine uurimisküsimus: kui palju kirjutasid praktikandid ja kutseaastal olevad õpetajad praktika ja kutseaasta jooksul rõõmudest ja kui palju muredest ning kuidas see muutus praktika ja kutseaasta eri perioodidel ning seostus kirjutise teemaga?

Nii praktika kui ka kutseaasta jooksul peaks toimuma õpetaja professionaalsuse kasv. Selle uurimiseks õpetajakoolituses on hinnatud sobivaimaks Fulleri ja Bowni (1975) mudelit (Conway \& Clark, 2003), kus esimeselt astmelt järgmisele saab liikuda lühikese aja jooksul, juba praktika alguses. Kuna praktikat peetakse õpetajakoolituse esimeseks etapiks ja kutseaastat teiseks etapiks, siis tõstatub küsimus, kuivõrd on kutseaastal osalejad juba kõrgemal õpetaja professionaalse arengu astmel võrreldes praktikal osalejatega ning kuidas professionaalse arengu staadiumid muutuvad praktika/ kutseaasta käigus. Samuti on see mudel seotud õpetajatöös esilekerkivate erinevate muredega, andes alust uurida, kuidas õpetaja professionaalse arengu staadiumid seostuvad praktika/kutseaasta jooksul esinevate murede-rõõmudega. Eeltoodut arvesse võttes püstitati kolmas uurimisküsimus: kuidas kajastub õpetaja professionaalne areng Fulleri ja Bowni (1975) murede mudeli alusel praktikantide ja kutseaastal olevate õpetajate blogipostitustes ning kuidas see muutus praktika ja kutseaasta eri perioodidel ning seostus kirjutise sisuga?

\section{Metoodika}

Uurimuses püstitatud eesmärgi saavutamiseks tehti 2010/11. ja 2012/13. õppeaastal praktika ja kutseaasta raames kvantitatiivne uurimus. Kaardistav uurimisstrateegia valiti seepärast, et see sobib vähe tuntud nähtuse kirjeldamiseks (Cohen, Manion, \& Morrison, 2007).

Praktika kestis nendel õppeaastatel eri õppekavadel 7-12 nädalat. Õpetajakoolituse tudengid olid jaotatud eri koolide/lasteaedade vahel. Ühest haridusasutusest võis ühelt õppekavalt olla 1-4 üliõpilast. Igal praktikandil oli haridusasutuse määratud juhendaja. Mõnikord oli juhendajaid rohkem kui üks, näiteks üks aineõpetaja põhikooliastmest ja teine gümnaasiumiastmest, kolmandaks juhendajaks võis olla õpetaja, kelle klassile oli praktikant klassijuhatajaks. Lisaks käisid praktikandi tunde vaatlemas ülikooli didaktika ja üldpedagoogika õppejõud. Praktikantide ülesanne 
praktika jooksul oli tunde vaadelda, ette valmistada ja läbi viia, lisaks pidid nad korraldama klassiväliseid üritusi, osalema kooliüritustel, suhtlema lapsevanematega ning osalema kooli õppenõukogudes.

Kutseaasta on mõeldud õpetajatele, kes töötavad haridusasutuses esimest aastat. Selle aasta vältel on igal algajal ópetajal oma haridusasutusest mentor, kelleks võib olla ka mõne teise aine õpetaja. Lisaks toimuvad ülikoolis seminarid, mida juhivad kaks kogenud õpetajat. Kutseaasta jooksul täidab algaja õpetaja kõiki õpetaja ülesandeid ja kannab täisvastutust õpetajatöö eest. Ta saab pidada nõu oma mentoriga, mentor käib tema tunde vaatlemas ning annab nende kohta tagasisidet. Ülikooli seminarides arutatakse tekkinud probleeme ning püütakse neile lahendusi leida.

2010/11. óppeaastal otsustati praktika ja kutseaasta jooksul kasutada praktikantide ja algajate õpetajate toetamiseks kollektiivseid blogisid. Võimalus blogiga liituda anti kõigile soovijatele. Blogisid otsustasid sel õppeaastal kasutada kolm kutseaasta rühma Tallinna Ülikoolist ja üks rühm Tartu Ülikoolist, Tallinna Ülikoolist klassiõpetajate õppekaval õppivad üliõpilased ning Tartu Ülikoolist koolieelse lasteasutuse, põhikooli mitme aine õpetajate, matemaatikaõpetajate, ajalooõpetajate, emakeeleõpetajate, võõrkeeleõpetajate ja usundiõpetajate õppekava üliõpilased. Blogides toetasid õppijaid tuutorid (igas blogis 1-2 inimest). 2012/13. õppeaastal liitusid blogidega kolm Tallinna Ülikooli ja kolm Tartu Ülikooli kutseaasta rühma, Tallinna Ülikooli klassiõpetajate õppekaval õppivad üliõpilased ning Tartu Ülikooli koolieelse lasteasutuse, põhikooli mitme aine õpetajate, kehalise kasvatuse õpetajate, ajalooõpetajate, emakeeleõpetajate ja võõrkeeleõpetajate õppekava üliõpilased. Blogides toetasid õppijaid tuutorid, kuid seekord oli neid rohkem - iga blogi kohta 2-4 inimest.

2010/11. õppeaastal lõi uurimisrühm 13 kollektiivset blogi keskkonnas blogspot.com, osalejate arv blogides oli vahemikus 5-21. 2012/13. õppeaastal lõi uurimisrühm samas keskkonnas 17 kollektiivset blogi, milles osalejate arv jäi vahemikku 6-23. Osalejate arv blogides sõltus rühma suurusest. Eetilisuse tagamiseks arvestati uuringus Coheni ja tema kolleegide (2007) soovitust, mis hõlmab informeeritud nõusoleku nelja kriteeriumit: vastajate kompetentsus, vabatahtlikkus, informeeritus ja arusaamine uuringu olemusest. Et vastata nendele kriteeriumitele, tutvustati mõlemal õppeaastal eelseminaris osalejatele blogikeskkonda, aidati neil sinna konto luua ja teha esimene postitus blogisse, seejuures rõhutati, et blogi kasutamine on vabatahtlik ning selles osalemine ei mõjuta praktika või kutseaasta läbimist. Kõik blogid olid kinnised, mis tähendab, et sinna said kirjutada ja seal olevaid postitusi lugeda vaid konkreetse kollektiivse blogi liikmed. 


\section{Valim}

Uuringus võisid osaleda kõik nendel õppeaastatel praktikal olevad üliõpilased ning kutseaastat läbivad algajad õpetajad. Kuigi blogisid tutvustaval seminaril aidati kõigil teha esimene blogipostitus, kuulusid valimisse siiski vaid need osalejad, kes kirjutasid blogisse vähemalt kahel korral. Kokku oli selliseid osalejaid 243. 2010/11. õppeaastal oli valimis 95 ning 2012/13. õppeaastal 148 blogijat. Täpsem valimi kirjeldus on toodud tabelis 1 .

Tabel 1. Uuringus osalenute kirjeldav statistika

\begin{tabular}{l|c|c|c}
\hline & $2010 / 11$. õa & $2012 / 13$. õa & Kokku \\
\hline Õpetajakoolituse üliõpilasi & $58(61,1 \%)$ & $74(50 \%)$ & $132(54,3 \%)$ \\
\hline Algajaid õpetajaid & $37(38,9 \%)$ & $74(50 \%)$ & $111(45,7 \%)$ \\
\hline Kokku & $95(100 \%)$ & $148(100 \%)$ & $243(100 \%)$ \\
\hline Naisi & & & \\
\hline Mehi & $90(95 \%)$ & $110(74 \%)$ & $200(82,3 \%)$ \\
\hline Keskmine vanus (standardhälve) & $5(5 \%)$ & $38(26 \%)$ & $43(17,7 \%)$ \\
\hline Koolieelse lasteasutuse õpetajaid & $30(32 \%)$ & $40(27 \%)$ & $70(28,8 \%)$ \\
\hline Klassiõpetajaid & $23(24 \%)$ & $15(10 \%)$ & $38(15,6 \%)$ \\
\hline Aineõpetajaid & $42(44 \%)$ & $93(63 \%)$ & $135(56,6 \%)$ \\
\hline
\end{tabular}

\section{Andmete kogumine}

Blogi tutvustavas avaseminaris täitsid kõik osalejad ankeedi, milles küsiti nende taustaandmeid. Et tagada anonüümsus, mida peavad Cohen ja tema kolleegid (2007) uurimuse objektiivsuse saavutamiseks oluliseks, teavitati kõiki osalejaid, et nad võivad luua endale Gmaili aadressi, mis ei seostu nende nimega. Mitmed kasutasidki seda võimalust. Lisaks olid uurijatel eelseminaris kaasas kontod, mida sai vajaduse korral soovijatele anda. Ka need olid sellised, kus osalejat polnud võimalik nimega seostada, näiteks praktikant17. Uurimuse põhiandmed koguti blogipostitustest. Selleks kopeeriti esmalt kõigi blogide postitused Wordi failidesse. Kokku saadi 1900 blogipostitust (2010/11. õppeaastal 1102 ja 2012/13. õppeaastal 808 postitust). Postituste keskmine pikkus oli 176,1 sõna (standardhälve 213,8). Kõigile postitustele lisati blogidest kuupäev, millal need oli tehtud, blogija nimi ning märge, kas tegemist oli uue postituse või kommentaariga. 


\section{Andmeanalïïs}

Weberi (1990) sõnul on analüüsi ühiku määramine üks olulisimaid teksti sisuanalüüsi samme. Ka siinse uurimuse tarbeks määrati kindlaks postituse analüüsi ühik, milleks sai segment. Schillingu (2006) definitsiooni kohaselt on segment teksti osa, mis sisaldab ühte episoodi, ideed või informatsiooniosa ja mis on mõistetav eraldiseisvalt. Praegusel juhul on segment tervikpostitus või postituse osa, mis on ühel teemal. Saadud segmentide arv ja keskmine pikkus on esitatud tabelis 2 .

Tabel 2. Segmentide arv ja pikkus sõnades

\begin{tabular}{|c|c|c|c|}
\hline & 2010/11. õa & 2012/13. õa & Kokku \\
\hline \multicolumn{4}{|l|}{ Segmentide arv } \\
\hline Praktika blogid & 1384 & 753 & 2137 \\
\hline Kutseaasta blogid & 335 & 529 & 864 \\
\hline Kokku & 1719 & 1282 & 3001 \\
\hline \multicolumn{4}{|c|}{ Segmentide keskmine pikkus sõnades (standardhälve) } \\
\hline Praktika blogid & $114,2(145,8)$ & $145,8(122,9)$ & $125,6(138,9)$ \\
\hline Kutseaasta blogid & $60,1(60,3)$ & $112,9(145,7)$ & $90,6(120,2)$ \\
\hline Kokku & $102,2(136,6)$ & $132,4(133,6)$ & $115,1(134,4)$ \\
\hline
\end{tabular}

Blogisegmentide analüüsimiseks kasutati deduktiivset sisuanalüüsi. Kvantitatiivne sisuanalüüs arvestab ainult eksplitsiitset sisu, mida saab panna arvudesse, erinedes selle poolest kvalitatiivsest sisuanalüüsist, mis võimaldab interpreteerida ja leida tähendusi sügavamalt. Kvantitatiivne sisuanalüüs on süstemaatiline ning seeläbi vähem subjektiivne (Rose, Spinks, \& Canhoto, 2014). Blogipostituste analüüsimiseks koostas uurimisrühm (peale artikli autorite kuulusid sinna ka Karmen Kalk ja Olivia Voltri) täpse kodeerimisjuhendi. Väljatöötatud juhendit arutati ja täiendati koostöös teiste teadlastega, sealhulgas kaasati ka ekspert Marion FokkensBruinsma Hollandi Gröningeni ülikoolist. Kodeerimisjuhend ja skaalade näited on toodud lisas 1 .

Esmalt valiti välja 20 segmenti, mille iga uurija kodeeris sõltumatult (esimeses etapis kodeeris peale artikli autorite ka Karmen Kalk, teises etapis lisandusid Olivia Voltri ja Karin Naruskov). Kodeeringud vaadati üle ning leiti kooskõlamäär (agreement proportion). Sama tegevust korrati veel seitsmel korral, kuni saavutati kooskõlakordaja, mis oli kõigis alamkategooriates vähemalt $83 \%$. Edasi jaotati blogid uurijate vahel ära (igaüks sai 
nii praktika kui ka kutseaasta blogisid) ning iga uurija kodeeris oma blogisid eraldi. Vahepeal saadi kokku ning kodeeriti koos uuesti, et selgitada välja, ega kooskõlamäär pole vahepeal langenud. Segmendid, mille suhtes tekkis kodeerijal kahtlusi, saadeti uurijate meeskonnale arutamiseks. Veendumaks, et kodeerijad ei kodeerinud erinevalt, võrreldi alamkategooriaid kõigi kodeerijate lõikes ning statistiliselt olulist erinevust ei leitud (kõigil juhtudel $p>0,05$ ).

Segmendi postitamise kuupäeva abil arvutati muutuja „praktika/kutseaasta periood". Kuna praktikad olid eri pikkusega (7-12 nädalat), samuti erines Tallinna Ülikooli ja Tartu Ülikooli kutseaasta pikkus, siis jagati nii praktikad kui ka kutseaastad algus- ja lõpukuupäeva järgi seitsmeks perioodiks. Iga segment sai endale väärtuse 1-7 vastavalt sellele, millisel praktika või kutseaasta perioodil oli postitus tehtud.

Andmeanalüüsiks kasutati programmi IBM SPSS Statistics 22, millega arvutati alamkategooriate esinemise protsendid. Jaotusi võrreldi kahe teguri $\chi^{2}$-testiga, tunnuste võrdlemiseks kasutati Wilcoxoni testi ning praktika ja kutseaasta rühmade võrdlemiseks Mann-Whitney $U$-testi.

\section{Tulemused}

\section{Teemad, millest kirjutati blogides}

Praktikal olevate üliõpilaste (edaspidi: praktikandid) ning kutseaastat läbivate algajate õpetajate blogipostituste teemade osakaal on esitatud joonisel 1.

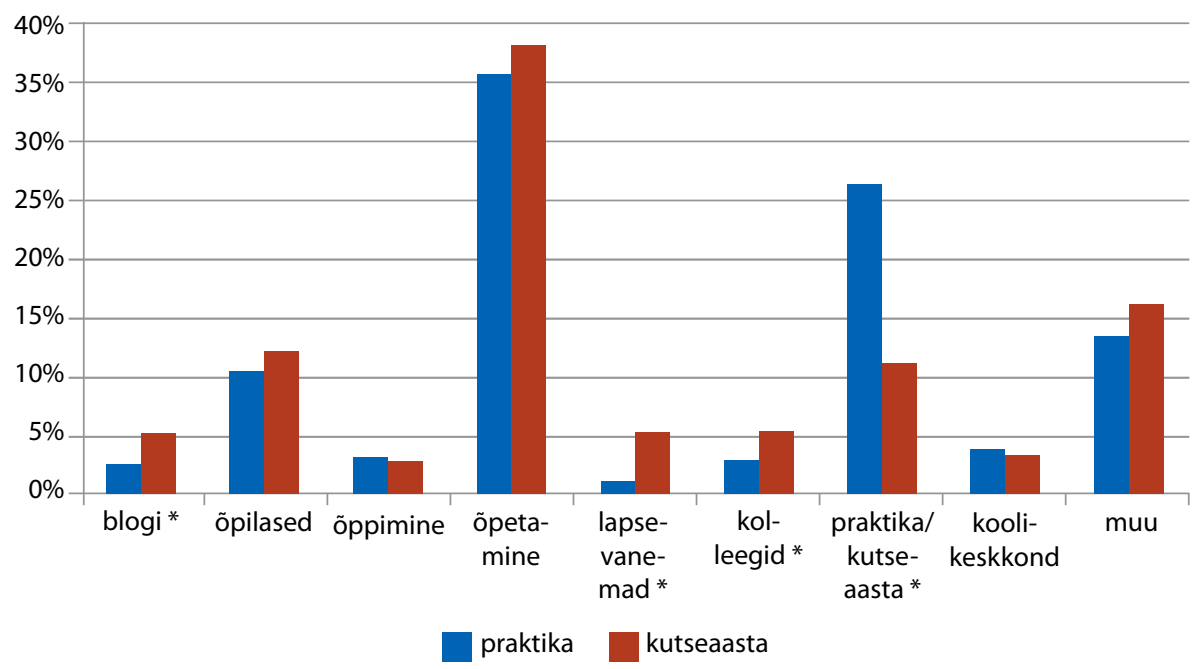

Joonis 1. Praktikantide ja algajate õpetajate blogipostituste teemade osakaal.

* - statistiliselt oluline erinevus praktikantide ja algajate õpetajate vahel $(p<0,01)$ 
Kõige rohkem kirjutasid mõlemad rühmad õpetamise teemadel (praktika blogides 35,7\% segmentidest ja kutseaasta blogides 38,1\% segmentidest). Praktika blogides oli õpetamise teema rohkem esindatud võrreldes teisel kohal oleva praktika teemaga $(z=-5,492 ; p<0,01)$. Ka kutseaasta blogides leidus õpetamise teemal tehtud postitusi oluliselt rohkem võrreldes teisel kohal oleva muu teemaga $(z=-8,783 ; p<0,01)$. Praktika blogides kajastus kõige harvemini teema, mis oli seotud lapsevanematega (1,2\% segmentidest, statistiliselt oluline erinevus eelviimasel kohal oleva blogi teemaga: $z=-3,534 ; p<0,01$ ).

Blogis kajastatud teemade võrdlusest praktikantide ja algajate õpetajate lõikes ilmnesid statistiliselt olulised erinevused nelja teema puhul (joonisel 1 tärniga tähistatud teemad). Statistiliselt oluliselt rohkem oli praktikantide postituste hulgas praktikat ja selle korraldust käsitletavaid teemasid $(U=899725,5 ; p<0,01)$ ning statistiliselt vähem blogi, lapsevanemate ja kolleegide teemadel tehtud postitusi (vastavalt $U=884833,0$; $U=900$ 612,5; $U=783$ 612,5; kõigil kolmel juhul $p<0,01$ ), kui võrrelda neid algajate õpetajate postituste osakaaluga. Teiste teemade puhul statistiliselt olulisi erinevusi ei ilmnenud (kõigil juhtudel $p>0,05$ ).

Teemad, millest kirjutati rohkem, erinesid praktika eri perioodidel (vt joonis 2). Kui praktika esimesel poolel kirjutasid üliõpilased kõige rohkem praktikast (36,9\% selle perioodi kõigist segmentidest, erinevus õpetamise teemaga $z=-2,045 ; p<0,05)$, siis teisel perioodil oli juba suurem osakaal blogis õpetamist kajastavatel segmentidel (36,2\%, erinevus praktika teemaga $z=-3,027 ; p<0,01)$. Ka kolmandast kuni kuuenda perioodini oli õpetamise teema statistiliselt oluliselt rohkem esindatud kui praktika teema (vastavalt $z=-6,016 ; z=3,284 ; z=-3,005$, kõigil kolmel juhul $p<0,01 ; z=-2,352 ; p<0,05)$. Viimasel perioodil hakati jälle rohkem kirjutama praktikast ning nende kahe teema vahel olulist erinevust polnud $(z=-1,509 ; p>0,05)$. Teistest teemadest rohkem tõusid esile ka õpilastega seotud teemad, eriti neljandal perioodil (praktika keskel), kui nende osakaal polnud oluliselt erinev praktika teema omast (õpilaste teema esines $15,9 \%$ segmentidest ning praktika teema $18,0 \%$ segmentidest, $z=-0,500$; $p>0,05)$.

Algajad õpetajad kirjutasid kõigil perioodidel statistiliselt kõige rohkem õpetamisest võrreldes teiste teemadega (vt joonis 3, kõigil juhtudel $p<0,01$ ). Kui praktika blogides eristusid teistest perioodide lõikes kolm teemat (õpetamine, praktika ja õpilased), siis kutseaasta puhul eristus selgelt vaid õpetamise teema. 


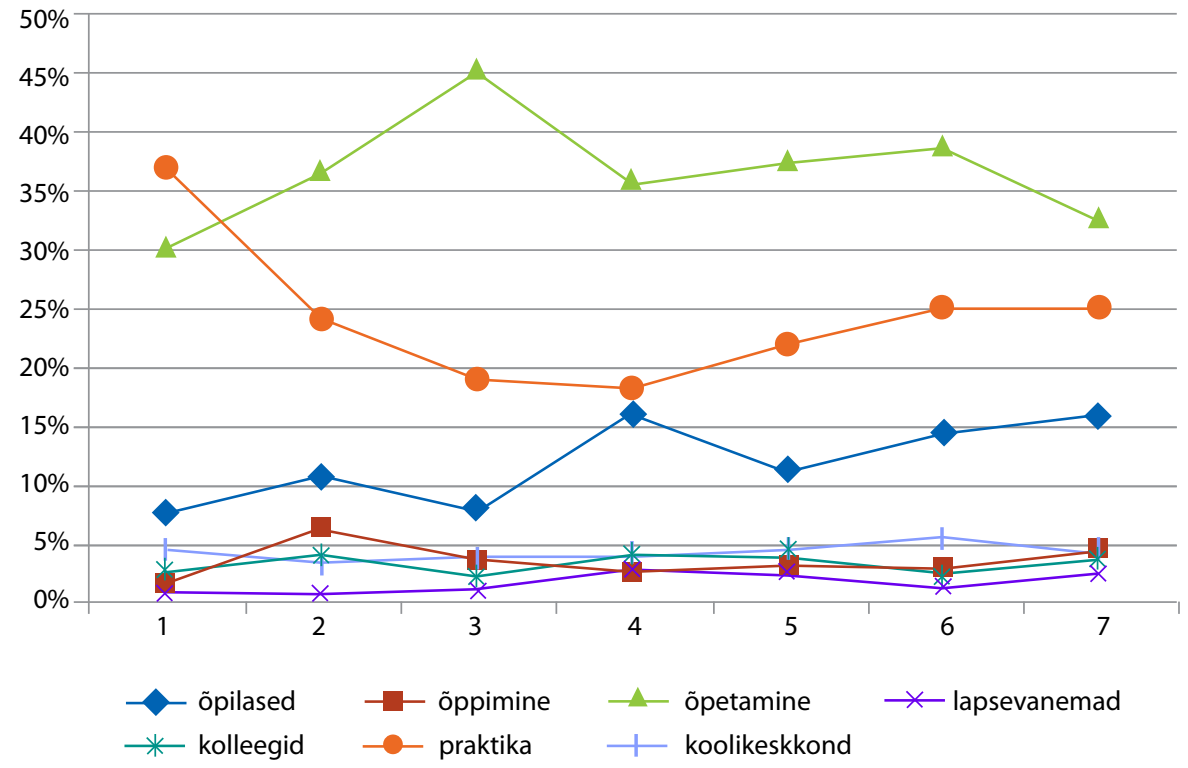

Joonis 2. Praktikantide blogipostituste teemade osakaal periooditi

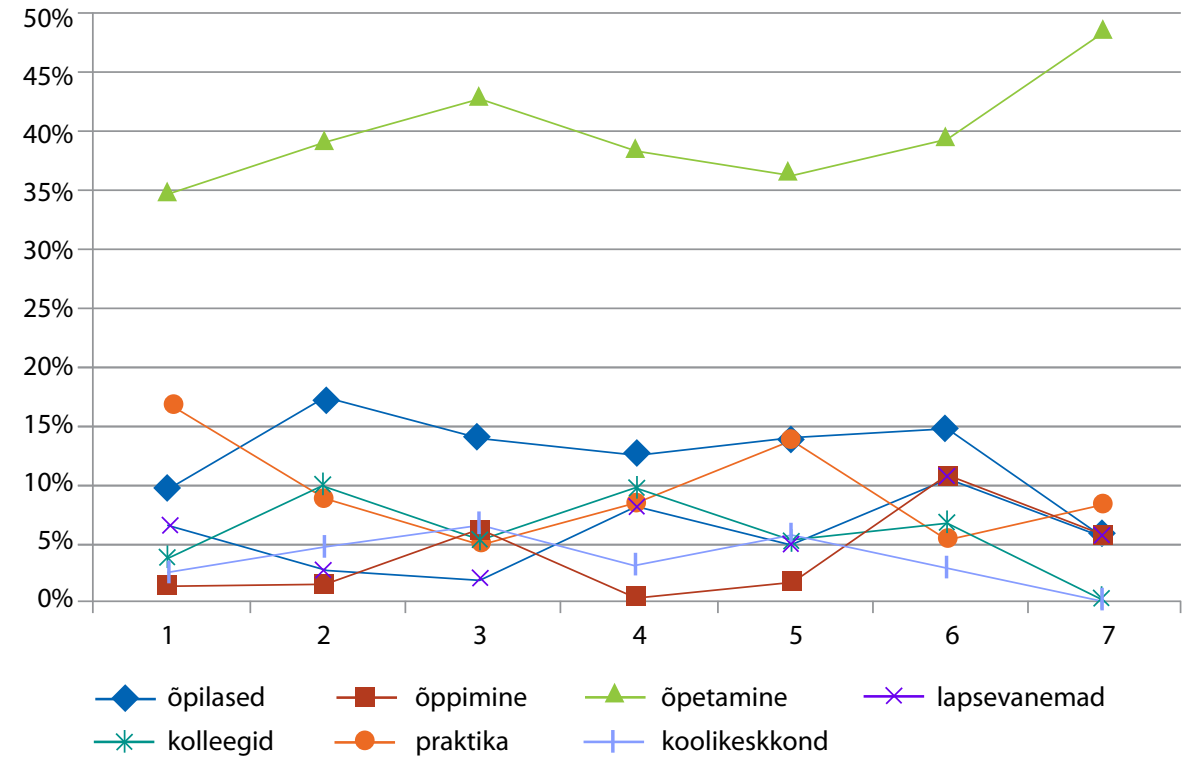

Joonis 3. Algajate õpetajate blogipostituste teemade osakaal periooditi 


\section{Rõõmude-murede kajastamine blogipostitustes}

Praktikantide blogis eristus 7,4\% segmentidest, kus räägiti enda või teiste ebaõnnestumistest, probleemidest, muredest, $80,4 \%$ segmentidest oli neutraalsel teemal ning 12,2\% segmentidest kajastas õnnestumisi, rõõme. Algajate õpetajate blogisid analüüsides ilmnes, et muredest kirjutisi esines 14,5\% segmentidest, neutraalset teemat käsitleti 73,1\% segmentidest ning rõõmudest kõneldi 12,3\% segmentidest. Praktikandid kirjutasid algajate õpetajatega võrreldes rohkem positiivsemas võtmes $(U=866055,5 ; p<0,01)$.

Üliõpilaste praktikablogides rõõmudest ja muredest kirjutatud segmentide osakaalud perioodide kaupa olid suhteliselt sarnased (vt joonis 4). Rõõmudest kirjutati statistiliselt rohkem võrreldes muredega esimesel ja seitsmendal perioodil (vastavad $\chi^{2}$-statistikud 10,316 ja 9,256; mõlemal juhul $p<0,01$ ). Ülejäänud perioodide puhul polnud statistiliselt olulist erinevust murede ja rõõmude kajastamises praktikablogis (kuuendal perioodil oli $\chi^{2}$-statistik 3,756; $p=0,06$ ja kõigil ülejäänud juhtudel $p>0,05)$. Kõige vähem kirjutati muredest esimesel ja viimasel perioodil (vastavalt $3,8 \%$ ja $4,5 \%$ nende perioodide segmentidest), samamoodi kirjutati esimesel perioodil kõige vähem ka rõõmudest $(8,3 \%$ selle perioodi segmentidest) võrreldes teiste perioodidega (kõigil juhtudel $p<0,05$ ).

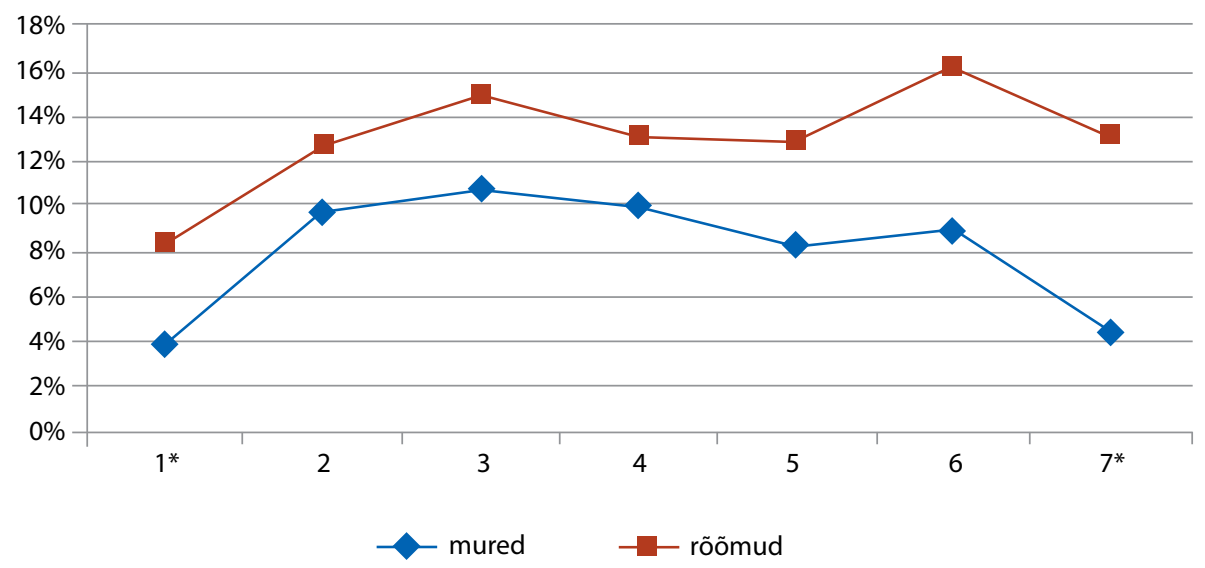

Joonis 4. Muredest ja rõõmudest kirjutatud segmentide osakaal perioodide kaupa praktikantide blogipostitustes

Kui praktikantide puhul jäi kõigil perioodidel rõõme kirjeldav joon ülespoole muresid kirjeldavast joonest, siis algajate õpetajate puhul on perioode, kus kirjutati rohkem muredest, ja perioode, kus kirjutati rohkem rõõmudest (vt joonis 5). Esimesel ja viimasel perioodil kirjutati 
statistiliselt oluliselt rohkem rõõmudest ( $\chi^{2}$-statistikud vastavalt 4,545 ja 3,946; mõlemal juhul $p<0,05$ ), samuti oli rõõmudest kirjutatud segmentide osakaal nendel perioodidel suurem kui teistel (vastavalt $17,0 \%$ ja $24,3 \% ; p<0,05)$. Teisel, viiendal ja kuuendal perioodil kajastati muresid aga suurema osakaaluga ( $\chi^{2}$-statistikud vastavalt 5,$261 ; 6,125$ ja 3,848; kõigil juhtudel $p<0,05)$. Kolmandal ja neljandal perioodil polnud rõõmudest ja muredest kirjutatud segmentide osakaalu vahel statistiliselt olulist erinevust $(p>0,05)$. Muredest kirjutati kõige vähem esimesel $(10,7 \%)$, neljandal $(11,0 \%)$ ja seitsmendal $(8,1 \%)$ perioodil võrreldes teiste perioodidega $(p<0,05)$. Erinevalt teistest perioodidest $(p<0,05)$ kajastati muresid kõige rohkem kuuendal perioodil $(23,7 \%)$.

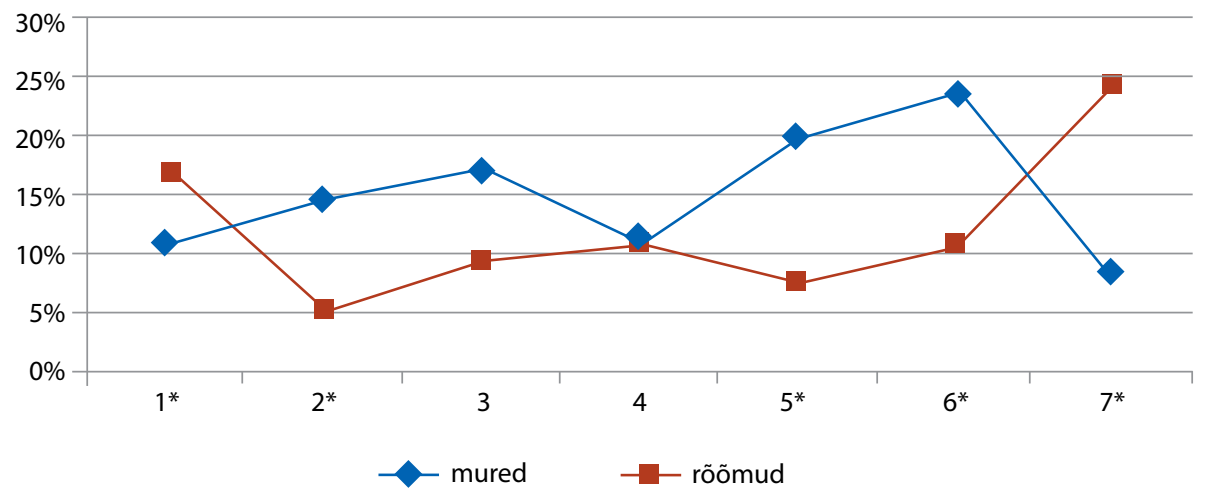

Joonis 5. Muredest ja rõõmudest kirjutatud segmentide osakaal perioodide kaupa algajate õpetajate blogipostitustes

Analüüsides, mis teemadel kirjutati rohkem seoses rõõmude ja mis teemadel rohkem seoses muredega, ilmnes, et üliõpilaste blogipostitustes (vt joonis 6) oli statistiliselt oluliselt enam kajastatud rõõme võrreldes muredega, kui kirjutati blogist, õppimisest, õpetamisest, kolleegidest ja praktikast $\left(\chi^{2}\right.$-statistikud vastavalt 4,$500 ; 7,118 ; 19,333 ; 12,565,9,720$; esimesel juhul $p<0,05$ ja neljal viimasel juhul $p<0,01)$. Teiste teemade puhul statistiliselt olulist erinevust ei ilmnenud ( $p>0,05)$. Siinkohal peab märkima, et lapsevanematest kirjutatud postituste arv oli liiga väike (6 postitust muredest ja 9 rõõmudest), et seda teemat võrrelda. 


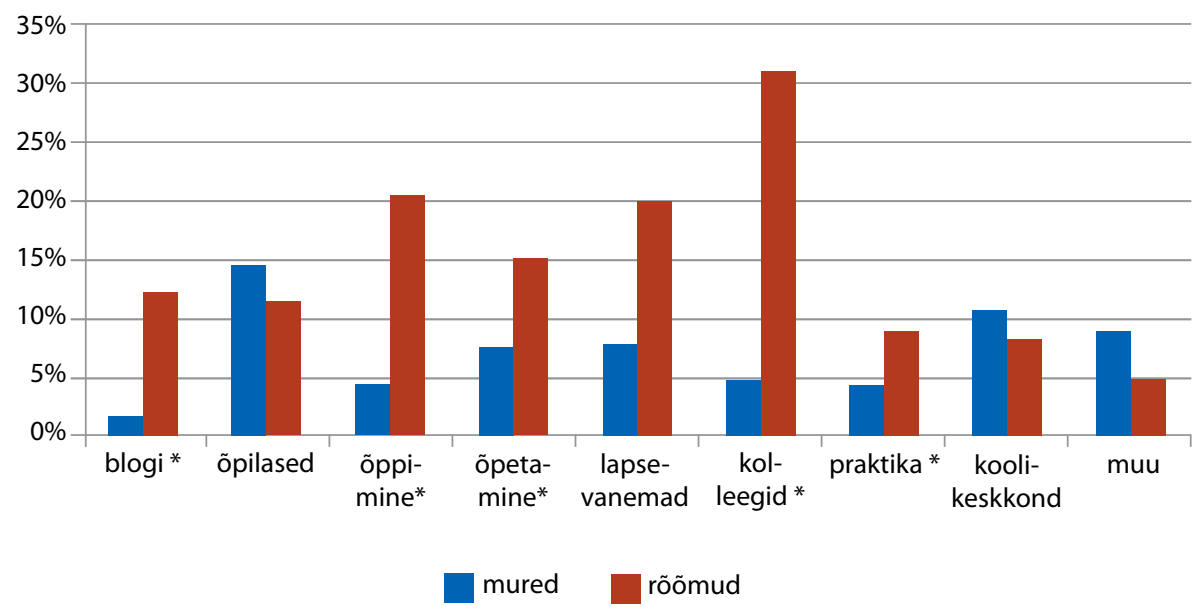

Joonis 6. Muredest ja rõõmudest kirjutatud teemade osakaal praktikantide blogipostitustes

Algajate õpetajate puhul ilmes statistiliselt olulisi erinevusi kahe teema puhul. Õpilaste teemal kirjutati rohkem muredest kui rõómudest $\left(\chi^{2}\right.$-statistik 13,000; $\left.p<0,01\right)$ ja kutseaasta korralduse teemal rohkem rõõmudest kui muredest $\left(\chi^{2}\right.$-statistik 5,$\left.000 ; p<0,05\right)$. Teiste teemade puhul statistiliselt olulisi erinevusi ei ilmnenud $(p>0,05)$, kuid lapsevanemate ja koolikeskkonna teemal oli postitusi võrdlemiseks liiga vähe (lapsevanemate puhul 16 postitust muredest ja 9 rõõmudest ning koolikeskkonna puhul 6 postitust muredest ja 3 rõõmudest).

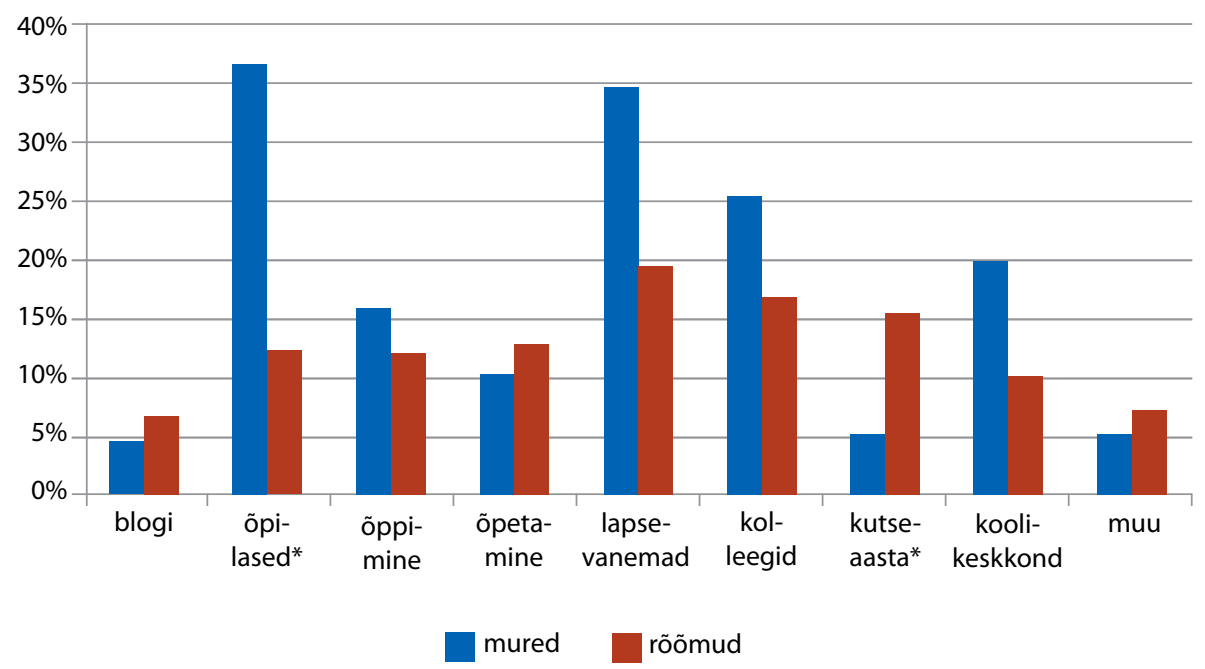

Joonis 7. Muredest ja rõõmudest kirjutatud teemade osakaal algajate õpetajate blogipostitustes 


\section{Õpetaja professionaalse arengu staadiumite kajastumine blogipostitustes}

Õpetaja professionaalse arengu staadiumite väljendumist analüüsiti 2105 $(70,1 \%)$ segmendil, mis sisaldasid õpetaja tööga seotud kirjutisi. Praktikantide blogides (vt joonis 8) esines kõige rohkem ellujäämise staadiumit (oluline erinevus võrreldes kõigi ülejäänud staadiumitega, $p<0,01$ ). Teisel kohal olid fantaasia-illusioonide ning õpetamise staadiumi postituste hulk (oluline erinevus võrreldes kahe ülejäänuga, $p<0,01$; olulist erinevust polnud nende kahe taseme vahel, $p>0,05)$. Kõige vähem esines praktikantide postitustes aga viimast staadiumit, kus hakatakse nägema oma õpetamise mõju õpilastele (statistiliselt oluline erinevus $z$-testi korral võrreldes kõigi ülejäänud staadiumitega, $p<0,01$ ). Algajate õpetajate blogipostitustest ilmnes statistiliselt oluline erinevus kõigi nelja staadiumi vahel. Kõige rohkem tehti postitusi ellujäämise staadiumis, sellele järgnes õpetamise staadium, õpilaste õppimisele mõju nägemise staadium ning viimasel kohal oli fantaasia-illusioonide staadium ( $z$-testiga kõigil juhtudel $p<0,01$ ).

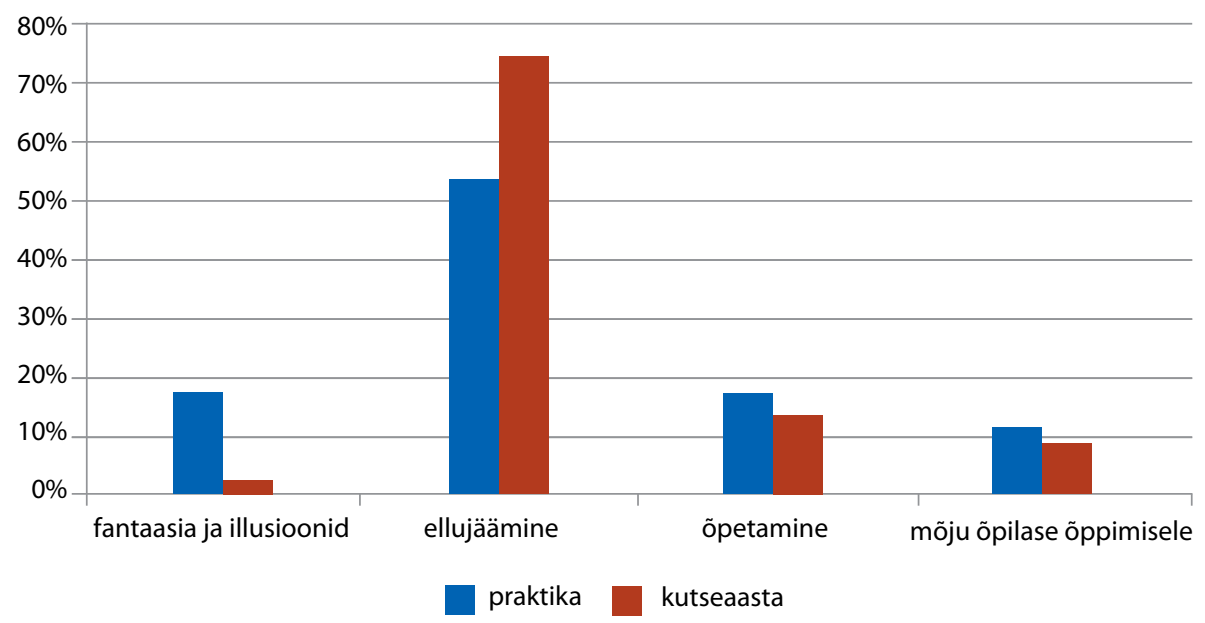

Joonis 8. Praktikantide ja algajate õpetajate blogipostituste segmentidest ilmnenud professionaalse arengu staadiumite osakaal

Praktikantide ja algajate õpetajate segmentide võrdlus (vt joonis 8) osutas statistiliselt olulisele erinevusele. Algajate õpetajate blogipostitustes väljendus kõrgem keskmine professionaalse arengu tase võrreldes praktikantide postitustega $(U=423049,5 ; p<0,05)$. Samas näitas üksikstaadiumite võrdlus, et ellujäämise staadiumit esines rohkem kutseaasta blogide segmentides (vastavalt 73,9\% ja 53,1\%, $\chi^{2}$-statistik 78,493; $p<0,01$ ) ning fantaasia-illusioonide ja ópetamise staadiumit rohkem praktikantide 
postitustes ( $\chi^{2}$-statistikud vastavalt 79,$676 ; p<0,01$ ja 4,044; $\left.p<0,05\right)$. Viimase staadiumi korral statistiliselt olulist erinevust nende kahe rühma vahel ei ilmnenud ( $\chi^{2}$-statistik 3,$\left.354 ; p>0,05\right)$.

Praktikantide postitustes (vt joonis 9) väljenduv professionaalse arengu tase suurenes juba teisel perioodil võrreldes esimese perioodiga $(U=28$ 170,5; $p<0,01)$. Praktikantide blogipostitustes teisel kuni kuuendal perioodil olulist erinevust õpetaja professionaalses tasemes polnud (kõigil juhtudel $p>0,05)$. Seitsmendal perioodil polnud küll statistiliselt olulist erinevust võrreldes kuuenda perioodiga $(U=10$ 840,5; $p>0,05)$, kuid õpetaja professionaalse arengu tase oli oluliselt madalam võrreldes viienda perioodiga $(U=11141,5 ; p=0,01)$.

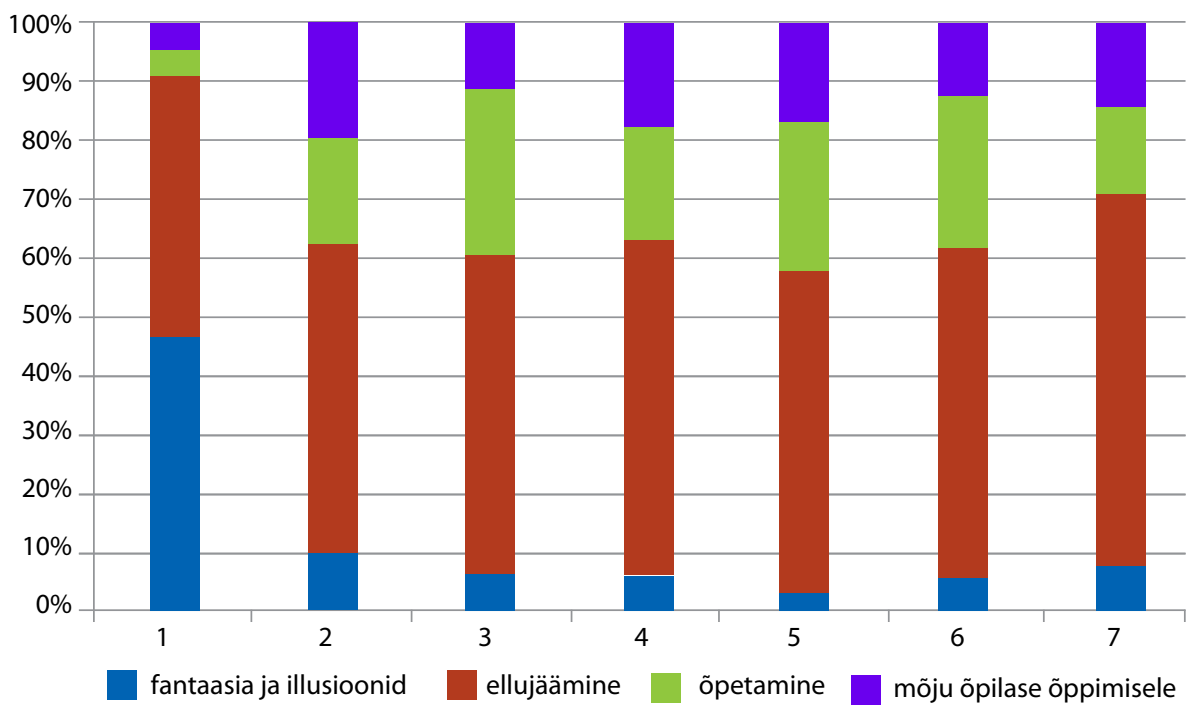

Joonis 9. Praktikantide blogipostituste segmentides kajastunud õpetaja professionaalse arengu staadiumite osakaal perioodide kaupa

Kui praktikantide blogides tehti fantaasia-illusioonide staadiumi postitusi läbivalt terve praktika jooksul, siis algajate õpetajate blogides esines neid vaid esimesel kolmel perioodil ja neidki maksimaalselt 6,4\% esimesel perioodil (vt joonis 10). Enamasti oli selle rühma korral kõigi perioodide puhul tegemist ellujäämise staadiumiga. 


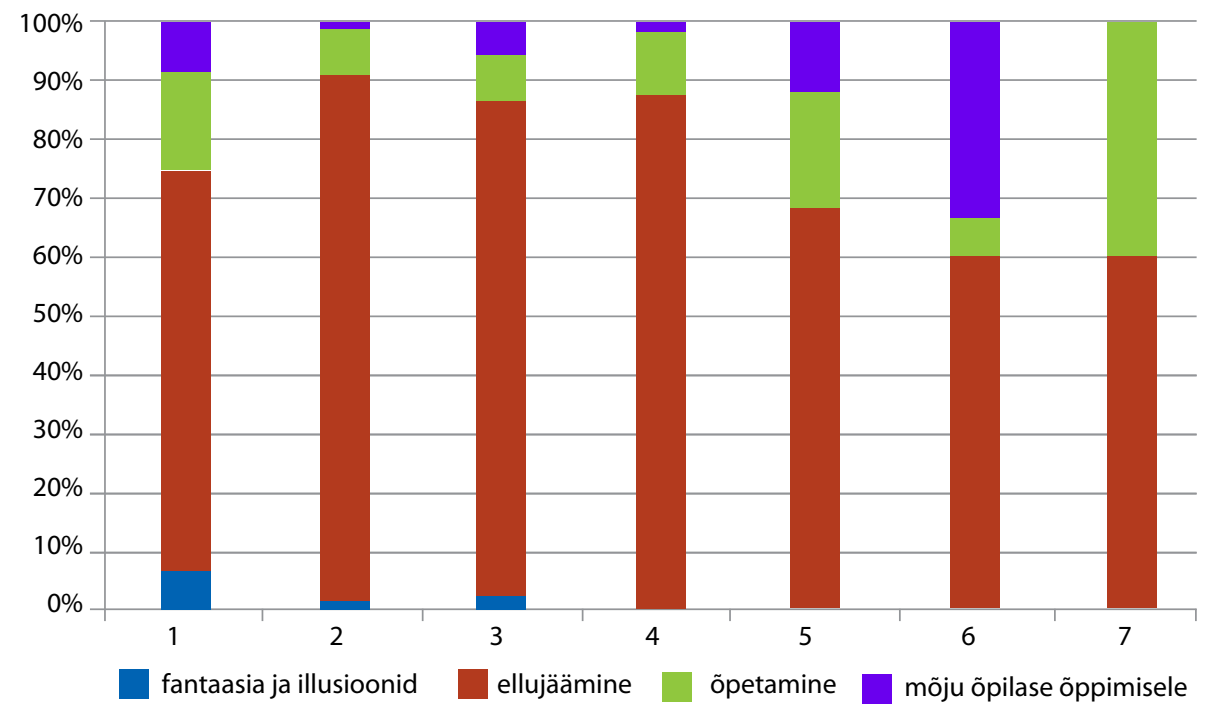

Joonis 10. Algajate õpetajate blogipostituste segmentides kajastunud õpetaja professionaalse arengu staadiumite osakaal perioodide kaupa

Algajate õpetajate blogide korral ei ilmnenud olulist erinevust õpetaja professionaalse arengu tasemes esimesel neljal perioodil (kõigil juhtudel $p>0,05)$. Kõige kõrgema professionaalse arengu tasemega olid kolm viimast perioodi, mis erinesid statistiliselt oluliselt kõigist teistest perioodidest $(p<0,05)$, kuid millel omavahel polnud statistiliselt olulist erinevust $(p>0,05)$. Siinkohal peab märkima, et viimasel perioodil oli kutseaasta blogidesse tehtud vaid 15 postitust, mille põhjal sai analüüsida õpetaja professionaalse arengu taset.

Õpilaste ja õpetamise teema korral ilmnes madalam professionaalse arengu tase praktika/kutseaasta korralduse segmentides (nii praktikantide kui ka algajate õpetajate puhul $p<0,01$ ). Statistiliselt olulist erinevust õpilaste ja õpetamise teema puhul ei olnud (mõlemal rühmal $p>0,05$ ). Võrreldes segmente, kus kirjutati muredest, segmentidega, kus kirjutati rõõmudest, ei ilmnenud statistiliselt olulist erinevust õpetaja professionaalse arengu tasemes kummagi rühma puhul (praktikantide blogides $U=13$ 244,5; $p>0,05$ ja algajate õpetajate blogides $U=4627,5 ; p>0,05$ ). 


\section{Arutelu}

\section{Teemade kajastumine blogipostitustes}

Tulemustest ilmnes, et kõige rohkem kirjutasid nii praktikandid kui ka algajad õpetajad õpetamise teemadel. Saadud tulemus on kooskõlas varasemate uurimuste omaga (nt Fisher \& Kim, 2013; Kiggundu \& Nayimuli, 2009; Mapfumo et al., 2012; Marais \& Meier, 2004; Mariko, 2011; Ozdemir \& Yildirim, 2012). Nii meie kui ka Rettigi (2013) uurimuse põhjal oli rohkem kui kolmandik kirjutistest õpetamise teemadel. Nagu ka varasemates uurimustes (Eisenschmidt, 2006b; Findlay, 2006; Poom-Valickis, 2007, 2014), kirjutasid ka praegusel juhul praktikandid ja kutseaastal osalevad õpetajad nii õpetaja ametist, selle väljakutsetest, endast kui õpetajast ning oma tegemistest õpetajana. Blogikaaslastega jagati õpetamisnippe ning küsiti neilt nõu õpetamisega seotud teemade kohta. Samuti arutleti suurte nõudmiste üle, kurdeti, et päeva lõpuks ollakse õpetamisest väsinud, nagu on osutatud ka praktikat käsitlevates uurimustes (nt Caires et al., 2012; Mapfumo et al., 2012) ning kutseaasta uurimustes (nt Findlay, 2006). Kutseaastal osalevate õpetajate postitustes domineeris õpetamise teema kõigil kutseaasta perioodidel.

Praktikandid kirjutasid palju praktika korraldusest ja nõuetest (ligemale veerand postitustest). Ka varasemate uurimuste põhjal on ühe olulise teemaplokina toodud välja teemad, mis on seotud praktika korraldusega (nt Kiggundu \& Nayimuli, 2009; Luik et al., 2011; Mapfumo et al., 2012; Ozdemir \& Yildirim, 2012; Rettig, 2013). Praktika korraldust kajastati blogides oluliselt rohkem kui kutseaasta oma. Praktika või kutseaasta korralduse teema alla loeti ka kõik postitused, kus kirjutati sellest, kui keegi käis tundi vaatlemas või analüüsiti koos juhendaja/mentoriga tundi või kuulati kellegi soovitusi-õpetusi. Seevastu kutseaasta blogides ei leidunud kummalgi õppeaastal ühtegi postitust, kus oleks räägitud koostööst oma mentoriga või tunnikülastustest. Samamoodi esitasid praktikandid ja algajad õpetajad blogides küsimusi praktika/kutseaasta nõuete kohta.

Rohkem kui kümnendik praktika ja kutseaasta jooksul tehtud postitustest oli õpilaste kohta. Seda on nimetanud olulise teemana ka teised autorid nii praktika (nt Mariko, 2011) kui ka kutseaasta puhul (Eisenschmidt, 2006b; Haggarty et al., 2011; Poom-Valickis, 2007). Blogikaaslastele kirjeldati oma õpilasi, nende käitumist üldiselt, kuid mitmed kirjutised olid ka konkreetse (enamasti probleemse) õpilase kohta.

Eelnimetatud kolm teemat - õpetamine, praktika ja õpilased - tõusid teiste teemadega võrreldes esile ka kõigil praktikaperioodidel. Sama tendents ei ilmnenud algajate õpetajate blogides: neil domineeris igal perioodil 
õpetamise teema ning teiste teemade osakaal suurenes ja vähenes olenevalt perioodist. Üks võimalikke põhjuseid võib olla asjaolu, et praktika aeg on märksa piiratum kui kutseaasta oma, mistõttu võib arvata, et selle aja jooksul tulevad kutseaasta perioodidel esile eri teemad. Kuna praktika kestus on lühem, siis kõigile teemadele ei jõua üliõpilased arvatavasti keskenduda.

Praktikantide teemadest kajastati kõige vähem lapsevanematega seotud teemat. Ka Rettigi (2013) uurimistulemuste põhjal oli sellel teemal kõige vähem postitusi ja peamiselt oli nendes postitustes juttu õpetaja-lapsevanema kohtumistest (arenguvestlused), nagu ilmneb ka meie uurimusest. Lapsevanematest kirjutati seoses arenguvestlustega ning juhul, kui probleemse õpilase vanemaga oli vaja kas telefonis või vahetult suhelda. Kutseaastal osalevate lasteaiaõpetajate postitustes oli lapsevanematest juttu ka lasteaia ürituste kontekstis. Kuna sel teemal kirjutasid rohkem algajad õpetajad, siis võib oletada, et praktikandid puutuvad lapsevanematega praktika jooksul vähem kokku, mis ka tingib nende selleteemaliste kirjutiste vähesuse. Seega võiks praktika jooksul anda neile rohkem ülesandeid, mis hõlmavad tööd lapsevanematega. Ka kolleegidest kirjutasid algajad õpetajad rohkem võrreldes praktikantidega, kuigi mõlemad puutuvad nendega oma töös ühtviisi kokku. Üks põhjuseid võib olla see, et praktikant ei jõua praktika jooksul tutvuda teiste õpetajatega koolis, vaid suhtleb enamasti ainult oma juhendajaga. Nii nagu varasemate uurimuste (Kiggundu \& Nayimuli, 2009; Ozdemir \& Yildirim, 2012) põhjal on leitud, võib probleem seisneda ka selles, et praktikante ei tutvustata teistele õpetajatele/ koolitöötajatele ja teised kolleegid ei respekteeri neid.

Üllatavalt vähe oli mõlema uuritava rühma puhul kirjutisi õppimisest. Kuna nii praktika kui ka kutseaasta on õpetajakoolituse osad, oleks enam oodanud kirjutisi sellest, mida nende jooksul õpiti. Varasemad uurimused (nt Fisher \& Kim, 2013) on näidanud, et oma postituste reflekteerimine võimaldab teha óppimise enda jaoks nähtavamaks. Kirjutistes on arutatud ka teooria ja praktika kooskõla üle (Marais \& Meier, 2004), kuid selliseid postitusi oli praeguse valimi puhul vaid üksikuid, mistõttu peaks nii praktikante kui ka algajaid õpetajaid rohkem suunama enda tegevusest õppima ning kõrvutama ülikoolis õpitavat reaalse koolikeskkonnaga.

\section{Rõõmude ja murede kajastumine blogipostitustes}

Huvitava tulemusena ilmnes, et algajate õpetajatega võrreldes kirjutasid praktikandid blogis rohkem oma rõõmudest. Samuti selgus, et kõigil praktikaperioodidel leidus praktikantide blogides rohkem postitusi rõõmudest võrreldes kirjutistega muredest. Vähemalt kolmveerand postitustest 
kõigil perioodidel oli aga neutraalse sisuga. Varasemad uurimused (Rettig, 2013) on leidnud, et praktika jooksul on postitused pigem rõõmsa alatooniga ning muredest kirjutatakse väga vähe. Samas oli algajate õpetajate blogipostitustes oluliselt rohkem postitusi rõõmudest vaid esimesel ja viimasel perioodil. Mitmel perioodil domineerisid nende blogides kirjutised muredest. Ka Merrill (2006) väidab, et algajad õpetajad vajavad võimalust jagada muresid kutseaastal ning blogi pakub neile selleks üht võimalust.

Põhjuseid, miks kutseaasta blogipostitustes oli praktikantide blogidega võrreldes rohkem juttu muredest nii üldises plaanis kui ka mitmel perioodil, võib olla mitmeid. Üheks võimalikuks seletuseks on asjaolu, et praktika ajal on üliõpilane enam toetatud: tal on peale koolipoolse(te) juhendaja(te) ka ülikoolist määratud juhendaja(d), kellega toimuvad regulaarsed arutelud. Praktikandid küll annavad praktika jooksul iseseisvalt tunde, kuid nendes viibib ka mõni juhendaja. Kuigi algajal õpetajal on oma koolis olemas mentor, võib juhtuda, et ta ei ole sama aine õpetaja ja ta ei saa oma töö tõttu algaja õpetaja jaoks alati kohal olla. Kutseaasta käigus toimuvad ülikooli juures ka seminarid, kuid need ei pruugi anda algajale õpetajale piisavat tuge. Kutseaasta on ka aeg, mil probleeme tekib üleminekul üliõpilase rollist õpetaja rolli ning kohanemisel kooli nõudmistega (Eisenschmidt, 2006b; Poom-Valickis, 2007), mida praktikandilt nii palju ei nõuta.

Praktikantide blogipostitustes oli oluliselt rohkem kajastatud rõõme kui muresid viie teema puhul. Kolm neist olid blogi, õppimise ja õpetamise kohta. Varasemate uurimuste tulemused (Rettig, 2013) on näidanud, et suurimad mured puudutavad praktikantide kirjutistes just ópetamise ja klassi juhtimise teemat, mis on praeguste tulemustega vastuolus. Vähemalt blogipostitustes jagasid praktikandid õpetamisega (sh kasvatustööga) seoses rohkem rõõme võrreldes muredega. Õpetamise teema korral ei ilmnenud kutseaasta rõõme ja muresid kajastavate segmentide osakaalus statistiliselt olulist erinevust, mis on samuti mõneti vastuolus varasemate tulemustega (Eisenschmidt, 2006c) - on leitud, et Eesti algajad õpetajad peavad kõige suuremaks mureks klassi juhtimist. Rõõmustav on aga nentida, et õppimise ja blogiga seotud kogemused valmistavad praktikantidele pigem rõõmu kui muret.

Praktikandid kirjutasid rohkem rõõmudest kui muredest, tehes postitusi ka praktika korralduse ning kolleegide kohta. Algajate õpetajate postituste hulgas oli kutseaasta korralduse teema puhul samuti rohkem kirjutisi rõõmudest. Ka varasemad uurimused on näidanud, et kutseaasta korraldusega ollakse Eestis pigem rahul kui mitterahul (Reiska \& Eisenschmidt, 2008). Kolleegide teema korral kutseaasta rõõmudest ja muredest kirjutatud 
postituste osakaalu vahel statistiliselt olulist erinevust ei ilmnenud, kuid tendentsi, et sellest teemast kirjutati rohkem negatiivsemas võtmes, võis küll täheldada, mis on samuti mõneti vastuolus varasemate uurimistulemustega (Eisenschmidt, 2006c).

Teemasid, mille korral oleks oluliselt rohkem postitatud muredest kui rõõmudest, praktikantide blogide analüüsimisel ei ilmnenud. Küll aga leidus selline teema kutseaasta õpetajate blogis - selleks oli õpilaste teema. Ka varasemad uurimused (Eisenschmidt, 2006b; Haggarty et al., 2011; Poom-Valickis, 2007) on toonud algajate õpetajate murekohana välja toimetuleku õpilaste käitumisega. Nähtavasti on tegemist teemaga, millele tuleks õpetajakoolituses rohkem tähelepanu pöörata.

\section{Õpetaja professionaalse arengu staadiumite kajastumine blogipostitustes}

Võttes andmete analüüsimisel aluseks Fulleri ja Bowni (1975) murede mudeli, leiti, et nii praktikantide kui ka algajate õpetajate postitustes olid mõlemas rühmas esindatud kõik professionaalse arengu staadiumid alates illusioonide staadiumist kuni viimase staadiumini, kus hakati nägema õpetaja tegevuse mõju õpilasele. On küll arvatud, et illusioonide staadium on omane pigem üliõpilastele (Õim, 2008), kuid praegused uurimistulemused näitasid, et see oli vähesel määral iseloomulik ka kutseaastal olijatele (see on uudne tulemus ja vääriks edasi uurimist). Võimalik, et uude keskkonda minnes alustatakse alati illusioonide staadiumist ning varasemad staadiumid läbitakse kiiremini kui esimesel korral.

Eri staadiumid kajastusid kutseaasta ja praktika rühmade postitustes erinevalt. Kõige rohkem oli mõlema rühma puhul esindatud ellujäämise staadium. See on üsna ootuspärane tulemus, arvestades, et ebareaalsed illusioonid purunevad kiiresti juba praktika ajal, mil saadakse esimesed õpetamiskogemused (Sinclair et al., 2006), kuid enesekeskne muretsemine enda toimetuleku ja n-ö ellujäämise pärast ning klassi ohjamise ja õpilaste käitumise juhtimisega seotud mured on leitud olevat ühtviisi aktuaalsed nii praktika (nt Fisher \& Kim, 2013; Mapfumo et al., 2012; Marais \& Meier, 2004; Ozdemir \& Yildirim, 2012; Rettig, 2013) kui ka kutseaasta korral (Eisenschmidt, 2006c). Üllatuslikult avaldus ellujäämise staadium oluliselt rohkem kutseaastal olijate postitustest, kuigi just praktika on esimene etapp, mil õpetajaks õppijad satuvad klassi ette. Võimalik, et praktikal olijad ei tunneta veel õpetajatöö kogu keerukust ja raskusi (praktika on lühiajalisem, toetust saadakse eeldatavasti mitmelt juhendajalt, klassil on oma päris õpetaja, kelle poole hädas pöörduda), mistõttu ei muretse nad enda 
pärast nii palju kui kutseaasta läbijad, kes peavad kandma juba täit vastutust kõigi õpetamise aspektide ning õpilaste õppimise ja arengu eest. Järgnevad staadiumid jaotusid erinevalt: praktikantide postitustes järgnesid ellujäämise staadiumile võrdselt illusioonide ja õpetamise staadium, kõige vähem postitusi oli tehtud staadiumis, mil hakati nägema õpetamise mõju õpilastele. Kutseaastal oli teisel kohal õpetamise ja kolmandal õpilastele mõju nägemise staadium, illusioonide staadiumit esines kõige vähem.

Praktikantide ja algajate õpetajate professionaalse arengu staadiumite muutused postitustes on üsna erinevad. Praktikantide professionaalse arengu tase tõusis postitustes kiiresti, olles juba teisel perioodil oluliselt kõrgem, kuid jäi edasise praktika käigus muutumatuks. Postitustest ilmnes illusioonide staadiumi osakaalu vähenemine ning õpetamise ja õpilasele mõju nägemise staadiumi osakaalu suurenemine alates teisest perioodist. Algajate õpetajate puhul olid muutused veidi teistsugused. Alates kutseaasta keskelt (neljandast perioodist) ei avaldunud postitustes enam illusioonide staadium, ellujäämise staadiumi osakaal vähenes märkimisväärselt ning kutseaasta teises pooles kolmel viimasel perioodil suurenes postitustes kahe kõrgema staadiumi (õpetamise ja mõju õpilase õppimisele) osakaal.

Praktika ja kutseaasta üldise sarnasusena võib välja tuua kaks joont. Esiteks, mõlema ajal väheneb postitustes ilmnenud kahe enesekesksema staadiumi osakaal ning kasvab õpetamisele ja õpilastele keskenduvate staadiumite osakaal. Teiseks, ellujäämise staadium on postitustes suhteliselt ülekaalukalt esindatud kogu praktika ja kutseaasta jooksul. Kuigi on arvatud, et umbes poole aasta pärast või varemgi jõuavad kutseaastal algajad õpetajad juba kolmandasse staadiumisse (Eisenschmidt, 2006a), sest ellujäämisega seotud mured (klassi juhtimine, distsipliiniprobleemid) on ületatud, on praeguste uurimistulemuste põhjal üllatav, et ellujäämise staadium esineb postitustes ka kutseaasta teisel poolel ja jääb domineerima läbi kogu kutseaasta.

Kõrgemal professionaalse arengu tasemel kirjutati õpilaste ja õpetamise teemast rohkem kui praktika/kutseaasta korralduse teemast. Samas ei leitud erinevust õpetaja professionaalse arengu taseme kajastamises neis segmentides, kus räägiti rõõmudest, võrreldes nendega, kus räägiti muredest. Olgugi et algajate õpetajate postitustes väljendati õpilaste teemaga seoses rohkem muresid, ei saa väita, et õpilaste teema korral oleks teiste teemadega võrreldes esinenud enam enesekeskset staadiumit. Kuigi Fulleri ja Bowni (1975) mudelit nimetatakse ka murede mudeliks, näitavad meie uurimistulemused, et õpetaja professionaalset arengut ei iseloomusta ainult mured, vaid ka rõõmud ja seega ei tahaks siinkohal nõustuda Conway ja Clarki (2003) väitega, et see mudel kallutab vaatama vaid õpetajatöö negatiivset poolt. 


\section{Uurimuse kokkuvõte ja piirangud}

Kokkuvõtvalt võib öelda, et põhiline teema, millest praktikandid ja algajad oppetajad kirjutavad, on õpetamine. Algajad õpetajad kirjutasid praktikantidega võrreldes vähem lapsevanematest ja kolleegidest. Kuigi nii praktika kui ka kutseaasta kuuluvad õpetajakoolituse alla, mille käigus peaks aset leidma õppimine, siis mõlema rühma kirjutistes esines õppimise teemat üllatavalt vähe. Samuti kirjutati vähem koolikeskkonnast. Seetõttu on soovitatav kavandada nii praktika kui ka kutseaasta puhul ülesanded nii, et käsitletaks ja analüüsitaks õpetajatöö eri tahke ning ka töökeskkonda. Et nendes etappides toimuks teadvustatud õppimine, tuleks rohkem tähelepanu pöörata oma tegevuse reflekteerimisele ning sellest õppimisele.

Rõõmude ja murede kajastamise kohta saab kokkuvõtvalt väita, et praktikantide blogides leidus kutseaasta blogidega võrreldes rohkem kirjutisi rõõmudest. Praktikantide puhul polnud ühtegi teemat, mille korral oleks rohkem kirjutatud muredest kui rõõmudest. Algajad õpetajad jagasid aga just õpilastest kirjutades rohkem just muresid. Selle põhjus võib seisneda juhendajapoolses toes, mistõttu tuleks kutseaastal osalejatele pakkuda rohkem ülikoolipoolset tuge. Samuti tuleks neile anda võimalus suhelda teiste kutseaastal olijatega ka seminaridevahelisel ajal, jagada oma muresid, saada teistelt abi või tunda lihtsalt, et nad pole oma olukorras üksi. Et algajad õpetajad tuleksid paremini toime õpilastega ning õpilaste teema ei tekitaks neile nii palju muret, võiks õpetajakoolituses rohkem tähelepanu pöörata tööle õpilastega, õpilaste erivajadustele ja käitumisprobleemidele.

Oppetajate professionaalse arengu analüüsist ilmnes, et kuigi nii praktika kui ka kutseaasta jooksul väheneb postitustes avaldunud kahe enesekesksema staadiumi osakaal ning kasvab õpetamisele ja õpilastele keskenduvate staadiumite osakaal, on ülekaalus ikkagi ellujäämise staadium. Ka see näitab, et mõlemad õpetajakoolituse etapid vajavad rohkem tuge nii koolipoolsetelt mentoritelt kui ka ülikooli õppejõududelt. Üllatav oli tulemus, et ellujäämise staadium avaldus oluliselt sagedamini kutseaastal olevate algajate õpetajate postitustes võrreldes praktika läbijatega. Seega peaks praegusest rohkem mõtlema just kutseaastal olijate peale ning selgitama välja, millist toetust ja mis mahus nad vajavad. Kuigi võib eeldada, et nad on oma professionaalses arengus praktikantidest kaugemale jõudnud, siis tegelikkuses võivad ka kutseaastal olijad vajada pakutavast enam toetust.

Uurimuse piirangutena võib esile tuua, et kõigi tulemuste puhul oli aluseks blogipostitustes kirjutatu, millest ei saa teha järeldusi algajate õpetajate või praktikantide tegelike mõtete, nende murede-rõõmude või professionaalse arengu staadiumi kohta. Kuna praktikandid ja algajad õpetajad on 
koormatud paljude, sh uute ülesannetega, ning neil on seetõttu suur töökoormus, siis võis juhtuda, et sellel ajal loobusid paljud osalejad blogisse kirjutamast või tegid vähe postitusi. Kuna blogipostituste tegemine oli vabatahtlik, võib see olla samuti piiranguks, sest Dengi ja Yueni (2013) väitel on vabatahtliku blogi korral blogimisaktiivsus väiksem kui kohustuslikus blogis. Samuti peab nimetama piiranguna, et tegemist oli kollektiivse blogiga, kus kirjutati eelkõige sellest, mida taheti teistega jagada. Kollektiivses blogis võivad ka teiste postitused mõjutada seda, mis teemadest ja kuidas kirjutatakse.

Teadlikkus ja arusaamine praktikantide ja algajate õpetajate kogemustest ning muredest-rõõmudest praktika ajal ja kutseaastal võivad pakkuda kasulikku teavet õpetajakoolituse jaoks. Tulevaste/algajate õpetajate ees seisvatest katsumustest teadlik olek annab võimaluse korraldada praktikat/kutseaastat ja toetada õppijaid nii, et nad kogeksid rohkem edu ja saaksid meeldivaid kogemusi, mitte ei puutuks kokku vaid raskuste ja probleemidega. Näiteks saavad kutseaasta seminaride planeerijad sellest artiklist vajalikku infot ja soovitusi selle kohta, mis teemad mis kutseaasta perioodil päevakorda tulevad, ning see võimaldab kavandada seminaride sisu. Samuti saavad siit vajalikku infot pedagoogilise praktika korraldajad, et koostada praktikantidele ülesandeid ning mentoritele juhendeid ja koolitusprogramme.

\section{Kasutatud kirjandus}

Agarwal, N., Liu, H., Tang, L., \& Yu, P. S. (2012). Modeling blogger influence in a community. Social Network Analysis and Mining, 2(2), 139-162.

doi: http://dx.doi.org/10.1007/s13278-011-0039-3

Barone, T., Berliner, D. C., Blanchard, J., Casanova, U., \& McGowan, T. (1996). A future for teaching education. Developing a strong sense of professionalism. In J. Sikula (Ed.), Handbook of research on teacher education (2nd ed., pp. 11091149). New York: Simon \& Schuster Macmillan.

Ben-Peretz, M., \& Kupferberg, I. (2007). Does teachers' negotiation of personal cases in an interactive cyber forum contribute to their professional learning? Teachers and Teaching: Theory and Practice, 13(2), 125-143.

Caires, S., \& Almeida, L. S. (2005). Teaching practice in initial teacher education: Its impact on student teachers' professional skills and development. Journal of Education for Teaching: International Research and Pedagogy, 31(2), 111-120. doi: http://dx.doi.org/10.1080/02607470500127236

Caires, S., Almeida, L. S., \& Vieira, D. A. (2012). Becoming a teacher: Student teachers' experiences and perceptions about teaching practice. European Journal of Teacher Education, 35(2), 163-178.

doi: http://dx.doi.org/10.1080/02619768.2011.643395 
Can, G., \& Ozdemir, D. (2006). Blogging in higher education: Theoretical and practical approach. Journal of Systemics, Cybernetics and Informatics, 4(6), 5-13.

Cohen, L., Manion, L., \& Morrison, K. (2007). Research methods in education (6th ed.). London: Routledge.

Conway, P. F., \& Clark, C. M. (2003). The journey inward and outward: A re-examination of Fuller's concerns-based model of teacher development. Teaching and Teacher Education, 19(5), 465-482. doi: http://dx.doi.org/10.1016/S0742-051X(03)00046-5

Dall'Alba, G., \& Sandberg, J. (2006). Unveiling professional development: A critical review of stage models. Review of Educational Research, 76(3), 383-412. doi: http://dx.doi.org/10.3102/00346543076003383

Deng, L., \& Yuen, A. H. K. (2013). Blogs in pre-service teacher education: Exploring the participation issue. Technology, Pedagogy and Education, 22(3), 339-356. doi: http://dx.doi.org/10.1080/1475939X.2013.802990

Eisenschmidt, E. (2006a). Õpetaja professionaalne areng ja selle toetamine. Külastatud aadressil http://www.htk.tlu.ee/opah/kontseptsioon/prof-1-areng.doc/view.

Eisenschmidt, E. (2006b). Kutseaasta kui algaja õpetaja toetusprogrammi rakendamine Eestis (doktoritöö). Tallinn: TLÜ Kirjastus.

Eisenschmidt, E. (2006c) (koost.). Kutseaasta rakendamine Eestis. Kutseaasta II etapi seire kokkuvõte 2005/2006. Tallinn: TLÜ Kirjastus.

Findlay, K. (2006). Context and learning factors in the development of teacher identity: A case study of newly qualified teachers during their induction year. Journal of In-service Education, 32(4), 511-532. doi: http://dx.doi.org/10.1080/13674580601025165

Fisher, L., \& Kim, D. (2013). Two approaches to the use of blogs in pre-service foreign language teachers' professional development: A comparative study in the context of two universities in the UK and the US. The Language Learning Journal, 41(2), 142-160. doi: http://dx.doi.org/10.1080/09571736.2013.790130

Fry, S. W. (2007). First-year teachers and induction support: Ups, downs, and in-betweens. The Qualitative Report, 12(2), 216-237.

Fuller, F. F., \& Bown, O. H. (1975). Becoming a teacher. In K. Ryan (ed.), Teacher education (pp. 25-52). Chicago, IL: University of Chicago Press.

Haggarty, L., Postlethwaite, K., Diment, K., \& Ellins, J. (2011). Improving the learning of newly qualified teachers in the induction year. British Educational Research Journal, 47(6), 935-954. doi: http://dx.doi.org/10.1080/01411926.2010.508513

Kiggundu, E., \& Nayimuli, S. (2009). Teaching practice: A make or break phase for student teachers. South African Journal of Education, 29(3), 345-358.

Luik, P., Voltri, O., Taimalu, M., \& Kalk, K. (2011). On the use of student teacher blogs during teaching practice. Procedia - Social and Behavioral Sciences, 11, 165-169. doi: http://dx.doi.org/10.1016/j.sbspro.2011.01.054

Mapfumo, J. S., Chitsiko, N., \& Chireshe, R. (2012). Teaching practice generated stressors and coping mechanisms among student teachers in Zimbabwe. South African Journal of Education, 32(2), 155-166.

Marais, P., \& Meier, C. (2004). Hear our voices: Student teachers' experiences during practical teaching. Africa Education Review, 1(2), 220-233.

doi: http://dx.doi.org/10.1080/18146620408566281 
Mariko, S. (2011). Student teachers' reflective journals on teaching practice experiences. Contemporary PNG Studies: DWU Research Journal, 14, 67-83.

Merrill, S. (2006). Is the glass half full of half empty: Newly qualified teachers' perceptions of their progress at the midpoint of their induction year. Management in Education, 20(2), 29-35. doi: http://dx.doi.org/10.1177/089202060602000208

Mukeredzi, T. G., \& Mandrona, A. R. (2013). The journey to becoming professionals: Student teachers' experiences of teaching practice in a rural South African context. International Journal of Educational Research, 62, 141-151. doi: http://dx.doi.org/10.1016/j.ijer.2013.07.010

Ozdemir, A. A., \& Yildirim, G. (2012). The effects of teaching practice course on professional development of student teachers. Procedia - Social and Behavioral Sciences, 46, 2550-2555. doi: http://dx.doi.org/10.1016/j.sbspro.2012.05.520

Poom-Valickis, K. (2007). Algajate ópetajate professionaalne areng kutseaastal (doktoritöö). Tallinn: TLÜ Kirjastus.

Poom-Valickis, K. (2014). Novice teachers' professional development during the induction year. Procedia - Social and Behavioral Sciences, 112, 764-774. doi: http://dx.doi.org/10.1016/j.sbspro.2014.01.1228

Poulou, M. (2007). Student-teachers' concerns about teaching practice. European Journal of Teacher Education, 30(1), 91-110. doi: http://dx.doi.org/10.1080/02619760600944993

Reiska, E., \& Eisenschmidt, E. (koost.) (2008). Kutseaasta IV etapi seire kokkuvõte. Tallinna Ülikool. Külastatud aadressil http://dspace.utlib.ee/dspace;/bitstream/ handle/10062/40891/Uld_Kutseaasta2008.pdf?sequence $=1$.

Rettig, M. A. (2013). Online postings of teacher education candidates completing student teaching: What do they talk about? TechTrends, 57(4), 40-45. doi: http://dx.doi.org/10.1007/s11528-013-0676-7

Rose, S., Spinks, N., \& Canhoto, A. I. (2014). Management research: Applying the principles. New York: Routledge.

Schilling, J. (2006). On the pragmatics of qualitative assessments: Designing the process for content analysis. European Journal of Psychological Assessment, 22(1), 28-37. doi: http://dx.doi.org/10.1027/1015-5759.22.1.28

Sim, J. W. S., \& Hew, K. F. (2010). The use of weblogs in higher education settings: A review of empirical research. Educational Research Review, 5(2), 151-163. doi: http://dx.doi.org/10.1016/j.edurev.2010.01.001

Sinclair, C., Dowson, M., \& McInerney, D. M. (2006). Motivations to teach: Psychometric perspectives across the first semester of teacher education. Teacher College Record, 108(6), 1132-1154. doi: http://dx.doi.org/10.1111/j.1467-9620.2006.00688.x

Sivan, A., \& Chan, D. W. K. (2003). Supervised teaching practice as a partnership process: Novice and experienced student-teachers' perceptions. Mentoring \& Tutoring: Partnership in Learning, 11(2), 183-193.

doi: http://dx.doi.org/10.1080/13611260306853

Vavasseur, C. B., \& MacGregor, S. K. (2008). Extending content-focused professional development through online communities of practice. Journal of Research on Technology in Education, 40(4), 517-536.

doi: http://dx.doi.org/10.1080/15391523.2008.10782519 
Vescio, V., Ross, D., \& Adams, A. (2008). A review of research on the impact of professional learning communities on teaching practice and student learning. Teaching and Teacher Education, 24(1), 80-91.

doi: http://dx.doi.org/10.1016/j.tate.2007.01.004

Weber, R. P. (1990). Basic content analysis (2nd ed.). Newbury Park, CA: Sage Publications.

Õim, O. (2008). Algajate õpetajate professionaalne areng muutustena eneseefektiivsuse tajus (publitseerimata magistritöö). Tartu Ülikool, Tartu. 
Lisa 1. Segmentide sisu kodeerimise juhend

\begin{tabular}{|c|c|c|c|}
\hline Kategooria & $\begin{array}{l}\text { Alam- } \\
\text { kategooria }\end{array}$ & Kirjeldus & Näide \\
\hline \multirow[t]{5}{*}{ Teema } & Blogi & $\begin{array}{l}\text { Kirjutatakse blogist ja } \\
\text { blogimisest. }\end{array}$ & $\begin{array}{l}\text { Äkki võiks rohkem labeleid kasutada? } \\
\text { Nagu lisaks nimedele. On teistel pärast } \\
\text { lihtsam nõuandeid ja kogemusi leida. } \\
\text { Näiteks mul on praegu põhikooli } \\
\text { õpetamine käsil ja ma jätan kõik } \\
\text { gümnaasiumididaktika jutud sujuvalt } \\
\text { vahele. Paari nädala pärast tahaks kind- } \\
\text { lasti üle lugeda. Oleks need postitused } \\
\text { kõik gümnaasiumi sildiga, leiaks hästi } \\
\text { kiiresti üles. Analoogiline mõttekäik } \\
\text { kõigi teiste suuremate teemade kohta. }\end{array}$ \\
\hline & Õpilased & $\begin{array}{l}\text { Kirjutatakse õpilastest, } \\
\text { nende tegevusest, } \\
\text { käitumisest, välimusest, } \\
\text { probleemidest, } \\
\text { vajadustest jms. }\end{array}$ & $\begin{array}{l}\text { Lisandunud on „mõttetuid” noori ja } \\
\text { kahjuks mitmeid. Nägin täna vist kahte. } \\
\text { Kolmandaga pean veel mõtlema. } 8 \text { klassis } \\
\text { on üks poiss, kes lihtsalt istub pingis. } \\
\text { Asjad on laual, aga midagi lahti ei tee. } \\
\text { Küsisin, et kas sa ei teegi kaasa. Sain } \\
\text { vastuseks, et ma ei tea, mõttetu. Teises } \\
\text { klassis (ei mäleta, kas oli } 9 \text { või } 8 \text { ) istus } \\
\text { mingi vend, kellele pidid kogu aeg ütlema. } \\
\text { Tee vihik lahti, kirjuta see valem sinna. } \\
\text { Tõmba joonlauaga nüüd sirge. Ma oleks } \\
\text { küll jumala närvi läinud, õpetaja P ei } \\
\text { läinud. }\end{array}$ \\
\hline & Õppimine & $\begin{array}{l}\text { Kirjutatakse, mida } \\
\text { õpiti (ise ja õpilased), } \\
\text { kuidas õpitakse (ise } \\
\text { ja õpilased), kuidas } \\
\text { õppimist soodustada. }\end{array}$ & $\begin{array}{l}\text { Sõjaväes oli meil metsalaagris pesemis- } \\
\text { ópetus. kõik võtsid paljaks ja proovisid } \\
\text { ennast liitri veega pesta :). Tegelikult } \\
\text { mulle meeldis sõjaväeväljaõpe. tsiviilis } \\
\text { eeldatakse, et paljusid asju peaks loomu- } \\
\text { likust oskama. Seal seda ei eeldatud. Kõik } \\
\text { tehti läbi ka kõige labasem asi nagu paelte } \\
\text { sidumine. ja oli ôppida sealtki. }\end{array}$ \\
\hline & $\begin{array}{l}\text { Õpeta- } \\
\text { mine }\end{array}$ & $\begin{array}{l}\text { Kirjutatakse õpetaja } \\
\text { rollist, õpetamismeeto- } \\
\text { ditest, kasvatamisest, } \\
\text { arendamisest, õpeta- } \\
\text { misega seonduvast, ka } \\
\text { tundide ettevalmista- } \\
\text { misest, tööde paranda- } \\
\text { misest, klassivälisest } \\
\text { tööst. }\end{array}$ & $\begin{array}{l}\text { Lõpuks pidin veel üle vaatama mõned } \\
\text { lugemispäevikud, mis minuni alles täna } \\
\text { jõudsid. Panin ka nende laste viimased } \\
\text { hinded välja ja siis ka veel käitumise ja } \\
\text { hoolsuse hinded. Lõpuks kui koolimajast } \\
\text { välja astusin, oli kell } 18.30 . \\
\text { See on see õpetaja töö... :) }\end{array}$ \\
\hline & \begin{tabular}{|l} 
Lapse- \\
vanemad
\end{tabular} & $\begin{array}{l}\text { Kirjutatakse kodusest } \\
\text { keskkonnast, lapse pere- } \\
\text { konnast, suhtlemisest } \\
\text { lapsevanematega, prob- } \\
\text { leemidest, nende soovi- } \\
\text { dest, kodu ja perekonna } \\
\text { mõjust, arenguvestlustest. }\end{array}$ & $\begin{array}{l}\text { Ja tead, need lapsevanemad arvavad üldse } \\
\text { liiga palju ning arvavad, et õpetaja on } \\
\text { See, kes vastutab } 24 / 7 \text { nende lapse hea } \\
\text { käekäigu üle. }\end{array}$ \\
\hline
\end{tabular}




\begin{tabular}{|c|c|c|c|}
\hline Kategooria & \begin{tabular}{|l|} 
Alam- \\
kategooria
\end{tabular} & Kirjeldus & Näide \\
\hline & Kolleegid & $\begin{array}{l}\text { Kirjutatakse kõigest, } \\
\text { mis puudutab kolleege, } \\
\text { suhtlemist nendega, } \\
\text { koostööd. Siia alla } \\
\text { kuuluvad ka suhtlemine } \\
\text { ja koostöö kooli } \\
\text { juhtkonnaga. }\end{array}$ & $\begin{array}{l}\text { Õpetajate toas olid kaks vanemapoolset } \\
\text { prouat, kes üritasid midagi printida. } \\
\text { Üks pani printeri käima, see tegi oma } \\
\text { käivitumist tähistava urahtuse, mille peale } \\
\text { õpetaja ehmus: „Mis sa siis nüüd teed } \\
\text { siin?!” Teine rahustas teda: „Ära karda, } \\
\text { ega ta ei hakanud veel printima.” Need } \\
\text { ôpetajad vist infotehnoloogilisi vahendeid } \\
\text { tundides väga ei kasuta. }\end{array}$ \\
\hline & $\begin{array}{l}\text { Praktika/ } \\
\text { kutseaasta }\end{array}$ & $\begin{array}{l}\text { Kirjutatakse praktika ja } \\
\text { kutseaasta korraldusest, } \\
\text { esitatakse küsimusi } \\
\text { või vastatakse neile, } \\
\text { kirjutatakse sellest, } \\
\text { kuidas juhendatakse, } \\
\text { millised on nõuded. }\end{array}$ & $\begin{array}{l}\text { Nimelt kallid ülejäänud praktika tegijad, } \\
\text { kuidas teil lood õpimappidega? On keegi } \\
\text { juba ära viinud? Millal tuleb see ära viia } \\
\text { ja kas see lõpuseminari päev sai nüüd siis } \\
\text { paika või kuidas? (Ei julge enam praktika } \\
\text { üldjuhendajalt küsida, sest olen ta oma } \\
\text { kirjadega raudselt äärmiselt ära tüüdanud } \\
\text { :P) }\end{array}$ \\
\hline & $\begin{array}{l}\text { Kooli- } \\
\text { keskkond }\end{array}$ & $\begin{array}{l}\text { Kirjutatakse kooli või } \\
\text { lasteaia töökorraldusest, } \\
\text { kirjeldatakse oma } \\
\text { haridusasutust. Siia alla } \\
\text { kuuluvad ka füüsiline } \\
\text { ja psühholoogiline } \\
\text { koolikeskkond, } \\
\text { koolikultuur, identiteet, } \\
\text { missioon. }\end{array}$ & $\begin{array}{l}\text { Kooli õpikeskkond on väga hea ja toetav. } \\
\text { Õpilastele on antud väga kaasaegsed } \\
\text { materjalid ja klassid on varustatud } \\
\text { kaasaegse inventariga (suured telerid } \\
\text { pea igas klassis, korralik keemialabor ja } \\
\text { füüsika inventar, väga hästi arenenud } \\
\text { IT-valdkond - arvutiklassid, kooli enda } \\
\text { e-kooli lahendus, meediaklass jne). } \\
\text { See annab õpilastele võimaluse muuta } \\
\text { õppimist mitmekesisemaks ja teostada } \\
\text { praktilisi ülesandeid. Lisaks sellele } \\
\text { toimib koolis tugiõppe, parandusõppe ja } \\
\text { tunnirahu klassid - kõik selleks et toetada } \\
\text { õpilaste õppimist. }\end{array}$ \\
\hline & Muu & \begin{tabular}{|l} 
Kirjutatakse näiteks \\
endast, sõpradest, \\
jagatakse materjale, \\
infot, mis pole otseselt \\
seotud ei praktika/ \\
kutseaasta ega \\
haridusasutusega.
\end{tabular} & $\begin{array}{l}\text { Siis jooksin ma bussile, et jõuda oma } \\
\text { väikese õe lauluvõistlusele. Jõudsin täpselt } \\
\text { tema vanusegrupi alguseks. Ma olen } \\
\text { rahul, et otsustasin hoolimata hilinemisele } \\
\text { minna. Kuna mu õel läksid sõnad korra } \\
\text { meelest, siis pidi teda pärast laulmist } \\
\text { lohutama ja pisaraid pühkima, aga asja } \\
\text { tegi heaks tema tugev hääl ja lõpuks ta } \\
\text { võitis oma vanuses :) } \\
\text { Selle kiire jooksmisega, kui vahepeal läks } \\
\text { nahk märjaks ja siis oli külm tuul suutsin } \\
\text { ma end külmetada. Kurk on megavalus. } \\
\text { Joon meega teed ja võtan hoogu, et töid } \\
\text { parandama hakata. }\end{array}$ \\
\hline
\end{tabular}




\begin{tabular}{|c|c|c|c|}
\hline Kategooria & \begin{tabular}{|l|} 
Alam- \\
kategooria \\
\end{tabular} & Kirjeldus & Näide \\
\hline \multirow[t]{3}{*}{$\begin{array}{l}\text { Rõõmud ja } \\
\text { mured }\end{array}$} & Rõõmud & \begin{tabular}{|l|} 
Väljendatakse häid, \\
positiivseid, rõõmsaid, \\
õnnelikke tundeid, \\
eduelamust, rahulolu. \\
Esineb sellele viitavaid \\
märksõnu, nt hea, \\
hästi, suurepärane, olin \\
onnnelik, onnestus, läks \\
korda, rahul/rahulolu, \\
positiivne. Emotikonide \\
kasutamine ei kuulu \\
siia alla, kui tekstis pole \\
sõnade kaudu positiivset \\
meeleolu väljendatud.
\end{tabular} & $\begin{array}{l}\text { Üks meeletult hea kogemus oli ka } \\
\text { kolmapäevane eesti keele tund. Õpilased } \\
\text { õppisid ühest luuletusest pähe kolm } \\
\text { salmi. Salmid olid paariliste vahel } \\
\text { jaotatud. Esitlus toimus koos paarilisega. } \\
\text { Kõige kõige positiivsemaks asjaks osutus } \\
\text { see, et andsin kuulajatele ülesandeks } \\
\text { leida igast esitusest midagi positiivselt. } \\
\text { Kuulasime esitlused ära ning siis said } \\
\text { lapsed sõna. See oli nii armas, kuidas nad } \\
\text { analüüsisid ja teineteisele häid asju ütlesid } \\
\text { ja mitte niisama vaid kõik öeldu oli ka } \\
\text { asjakohane. Jäin sellega väga rahule, ei } \\
\text { osanud oodatagi, et nad nii hästi oskavad } \\
\text { analüüsida ja hinnata. Tore oli ka see, et } \\
\text { esinemine oli vabatahtlik ning pea kõik } \\
\text { klassist soovisid esineda. }\end{array}$ \\
\hline & Mured & $\begin{array}{l}\text { Väljendatakse kurbust, } \\
\text { viha, pettumust, } \\
\text { tüdimust, hirmu, } \\
\text { ebaõnnestumist. Esineb } \\
\text { märksõnu, mis on } \\
\text { negatiivse varjundiga, } \\
\text { nt ei meeldi, halb/ } \\
\text { paha, õudne, hirmus/ } \\
\text { hirmutav, lootsin ... } \\
\text { aga, kahjuks, kaugel } \\
\text { sellest, ebaõnnestus, } \\
\text { rahulolematu, } \\
\text { pahane. Emotikonide } \\
\text { kasutamine ei kuulu } \\
\text { siia alla, kui tekstis } \\
\text { pole sõnade kaudu } \\
\text { negatiivset meeleolu } \\
\text { väljendatud. }\end{array}$ & $\begin{array}{l}\text { Teatan ametlikult, et muusika õpetaja } \\
\text { mulle ei meeldi! Ta küll annab häid } \\
\text { soovitusi ja räägib, mis valesti teen. Aga! } \\
\text { Esiteks, küsisin kas ta sai mu meili kätte } \\
\text { (saatsin talle tunnikava). Mõnikord ju } \\
\text { ei jõua kirjad kohale ja mõnikord jääb } \\
\text { lugemisel kahesilma vahele. Nähvas } \\
\text { mulle, et muidugi sai, et meilid ju jõuavad } \\
\text { kohale, (ilusti oleks võind ju öelda „Jah”). } \\
\text { Teiseks. Ta ei vasta mu meilidele. Ma ei } \\
\text { tea, kas ta on neid lugenud? Ma nüüd ei } \\
\text { teagi, kas ma üldse pean homme tundi } \\
\text { andma või mitte. Ükspäev küsis mult, et } \\
\text { kas ma üldse tahan õpetajaks saada. Väga } \\
\text { selgelt oli aru saada, et ta pigem tahtis } \\
\text { öelda: „Minu arvates sa ei sobi õpetajaks”. } \\
\text { No, öelgu siis otse välja! }\end{array}$ \\
\hline & $\begin{array}{l}\text { Neut- } \\
\text { raalne }\end{array}$ & \begin{tabular}{|l|} 
Kirjutatakse neutraalselt, \\
kirjeldatakse või \\
analüüsitakse nii, et \\
mingeid emotsioone, \\
meeleolu ei oleks \\
võimalik välja lugeda. \\
Väljendatakse nii \\
õnnestumisi kui ka \\
ebaõnnestumisi. Näiteks \\
analüüsitakse ühe seiga \\
mõlemat tahku.
\end{tabular} & $\begin{array}{l}\text { Oma kogemusest võin öelda, et selline } \\
\text { ärritumine ja hääle tõstmine on tingitud } \\
\text { enese sisemisest ebakindlusest ja } \\
\text { kartusest, kas saan ikka hakkama. Kui see } \\
\text { möödub ja on julgust ning enesekindlust, } \\
\text { siis laabub kõik. Lapsed on väga nutikad } \\
\text { ja saavad koheselt aru, kui õpetaja kahtleb } \\
\text { endas ning kasutavad seda koheselt ära. }\end{array}$ \\
\hline
\end{tabular}




\begin{tabular}{|c|c|c|c|}
\hline Kategooria & \begin{tabular}{|l|} 
Alam- \\
kategooria
\end{tabular} & Kirjeldus & Näide \\
\hline \multirow[t]{4}{*}{$\begin{array}{l}\text { Õpetaja } \\
\text { professio- } \\
\text { naalse } \\
\text { arengu } \\
\text { staadium } \\
\text { Fulleri } \\
\text { ja Bowni } \\
\text { (1975) } \\
\text { mudeli } \\
\text { järgi } \\
\end{array}$} & \begin{tabular}{|l} 
Määra- \\
mata \\
(jäetakse \\
tühjaks)
\end{tabular} & $\begin{array}{l}\text { Ei kirjutata } \\
\text { ópetajatööst. Teemade } \\
\text { hulka kuuluvad } \\
\text { lühikommentaarid, } \\
\text { nt Pea vastu!, Ära lase } \\
\text { pead norgu!, Tubli oled!, } \\
\text { samuti uue aasta ja } \\
\text { jõulusoovid. }\end{array}$ & $\begin{array}{l}\text { Kui juba filosofeerimiseks läks, siis } \\
\text { targa inimese esimene tunnus on, et ta } \\
\text { tunnistab kui rumal ta on. }\end{array}$ \\
\hline & \begin{tabular}{|l|} 
Illusioo- \\
nide staa- \\
dium
\end{tabular} & $\begin{array}{l}\text { Kirjeldatakse muresid ja } \\
\text { ootusi enne õpetamist, } \\
\text { idealistlikke arvamusi. } \\
\text { Identifitseeritakse end } \\
\text { pigem õpilastega klassis, } \\
\text { mitte ei nähta end kui } \\
\text { ópetajat. }\end{array}$ & $\begin{array}{l}\text { Koridorid on täis sööklalõhna ja } \\
\text { lärmavaid lapsi, kes võivad sulle vabalt } \\
\text { peaga kõhtu (või mõnda teise õrna kohta, } \\
\text { kui nad on nooremast klassist) joosta. } \\
\text { Koolitunne tekkis nii sügavalt sisse - } \\
\text { kuid õpilase oma pigem - et kahe tunni } \\
\text { vahel linnas aega parajaks tehes tekkis } \\
\text { popitamise tunne. }\end{array}$ \\
\hline & $\begin{array}{l}\text { Ellu- } \\
\text { jäämise } \\
\text { staadium }\end{array}$ & $\begin{array}{l}\text { Tähtsal kohal on } \\
\text { enesekesksus, } \\
\text { käsitletakse enda } \\
\text { ja enesehinnangu/ } \\
\text { minapildiga seotud } \\
\text { teemasid, ellujäämist } \\
\text { haridusasutuses. } \\
\text { Kirjutatakse sellest, } \\
\text { mida on ise tehtud, } \\
\text { kuidas see õnnestus / } \\
\text { ei õnnestunud. Kirjutis } \\
\text { võib olla ka näiteks } \\
\text { õpetamisest, õpilastest, } \\
\text { aga kirjutatakse endast } \\
\text { lähtudes. }\end{array}$ & $\begin{array}{l}\text { Mul on keeruline olukord, kus tundideks } \\
\text { ette valmistamine hakkab pihta eelmisel } \\
\text { päeval, sest muul ajal nädalas on mu } \\
\text { oma tunnid või muud kohustused, } \\
\text { mida samuti ei anna edasi lükata. Seega } \\
\text { neljapäevased kaks tundi valmistan ette } \\
\text { pärast kolmapäevast ülikooli päeva ning } \\
\text { reedesed viis tundi pärast neljapäevaseid } \\
\text { antud tunde. Arvestades, et siiski iga } \\
\text { tund tuleb korralikult ette valmistada } \\
\text { ning seekord võtsin endale kindla suuna, } \\
\text { et kogu aruandlus peab paigas olema } \\
\text { jooksvalt, mitte et hiljem pean hakkama } \\
\text { meenutama, et mida tegin ja kuidas läks. } \\
\text { Seega on mu päevad olnud mega pikad } \\
\text { ning närvilisus kogunenud. }\end{array}$ \\
\hline & $\begin{array}{l}\text { Õpeta- } \\
\text { mise } \\
\text { staadium }\end{array}$ & \begin{tabular}{|l|} 
Keskendutakse \\
õpetamisele/ \\
metoodikale, \\
kirjutatakse õpetamisest, \\
teostusest, laste \\
tegevatest külgedest. \\
Veel ei nähta, kuidas \\
mõjutatakse oma \\
tegevuse kaudu õpilaste \\
õppimist (kas õpilased \\
ópivad või mitte). \\
\end{tabular} & $\begin{array}{l}\text { Jõuluhommikul korraldasin klassile } \\
\text { mõned koostöö ning üksteise } \\
\text { paremini tundma õppimise mängud. } \\
\text { Koostöömängude puhul pidi klass ühiselt } \\
\text { tegutsema ja üksteist aitama, et mingit } \\
\text { kindlat ülesannet täita. Üksteise suhtes } \\
\text { positiivset mõtlemist üritasin kujundada } \\
\text { selle kaudu, et andsin õpilastele ülesande } \\
\text { iga oma klassikaaslase kohta midagi head } \\
\text { kirjutada. }\end{array}$ \\
\hline
\end{tabular}




\begin{tabular}{|c|c|c|c|}
\hline Kategooria & $\begin{array}{l}\text { Alam- } \\
\text { kategooria }\end{array}$ & Kirjeldus & Näide \\
\hline & $\begin{array}{l}\text { Õpilastele } \\
\text { mõju } \\
\text { tajumise } \\
\text { staadium }\end{array}$ & $\begin{array}{l}\text { Saadakse aru õpetamise } \\
\text { mõjust õpilastele/ } \\
\text { óppimisele. Huvitutakse } \\
\text { sellest, kas õpilased ikka } \\
\text { ópivad, õpilasi nähakse } \\
\text { indiviididena, kel on } \\
\text { oma individuaalsed } \\
\text { vajadused. Tuuakse } \\
\text { paralleele sellega, mida } \\
\text { ópetati ja mida lapsed } \\
\text { óppisid. }\end{array}$ & $\begin{array}{l}\text { Otsustasin oma tunni alguses siis } \\
\text { kõigepealt kohe seda teemat käsitleda. } \\
\text { Esimene mõte, mis mul pähe tuli oli } \\
\text { oma sportlaskarjääri juba lõpetanud } \\
\text { Andrus Veerpalu ja tema suur konkurent } \\
\text { Frode Estil. Rääkisin neile, et sportis ja } \\
\text { võistlemises ongi alati nii, et on võitjad } \\
\text { ja kaotajad ja, et see käib ausa mängu } \\
\text { juurde. Et Veerpalu ja Estil olid ka } \\
\text { pidevalt võistlusrajal suured konkurendid, } \\
\text { aga see ei takistanud neil olla sõbrad. } \\
\text { Tundus, et see mõjus, sest vahetunnis olid } \\
\text { juba suhted head. }\end{array}$ \\
\hline
\end{tabular}




\title{
Experience related to teaching practice and participation in the induction year: The view through the blogs
}

\author{
Piret Luik $^{\mathrm{a} 1}$, Merle Taimalu ${ }^{\mathrm{a}}$ \\ ${ }^{a}$ Institute of Education, University of Tartu
}

\section{Summary}

\section{Introduction}

Teacher education includes both, the initial training of the teachers, as well as the subsequent induction year and in-service training. Both of these stages are quite similar in teacher education and teacher's professional development - practice is a part of the initial teacher education and the induction year is the second stage of teacher education.

Teaching, teacher role, classroom management and students' behaviour in teaching practice have been the most frequent topics in previous studies (e.g. Fisher \& Kim, 2013; Ozdemir \& Yildirim, 2012; Rettig, 2013). Classroom management is an important topic that causes problems in the induction year (Eisenschmidt, 2006b; Haggarty et al., 2011). Secondly, a number of studies have highlighted the topic of pupils both in practice (e.g. Rettig, 2013) and the induction year (Eisenschmidt, 2006b; Haggarty et al., 2011). The third group of topics, concerns and negative experiences were related to supervision of practice (e.g. Ozdemir \& Yildirim, 2012).

Several topics were represented by both poles - concerns as well as positive experiences. For example, supervision or mentor's work as concern (e.g. Ozdemir \& Yildirim, 2012) and satisfaction (e.g. Eisenschmidt, 2006c); topics of teacher work as concern (e.g. Rettig, 2013) and pleasure because of increased knowledge and skills (e.g. Poom-Valickis, 2014). Classroom management and coping with difficult students were the topics where only concerns were underlined (Eisenschmidt, 2006c; Haggarty et al., 2011; Rettig, 2013).

Several models are used to describe a teacher's professional development. One of them is classical, so called models of concerns. Later researchers have supplemented first, Fullers' three stage model in several ways - for example, making the four-stage model (Fuller \& Bown, 1975).

1 Institute of Education, University of Tartu, Salme 1a, 50103 Tartu, Estonia; piret.luik@ut.ee 
In this paper we have taken Fuller and Bown's model as a basis to analyse teacher's professional development.

The aim of this study is to identify what and how student teachers (ST) and newly qualified teachers (NQT) write in blogs during teaching practice and their induction year. The research questions are as follows:

- What are the topics that ST and NQT write about in their blogs during their teaching practice and the induction year? How did it change during different periods of the induction year and teaching practice?

- How much ST and NQT wrote about success and failure during their teaching practice and the induction year? How did it change during different periods of the induction year and teaching practice, and how was it related to the issue of posts?

- How teacher's professional development was reflected in posts written by ST and NQT? How did it change during different periods of the induction year and teaching practice, and how was it related to the issue of posts?

The survey among NQT and ST was carried out during the academic years of 2010/11 and 2012/13. The sample of the study consisted of 243 participants who wrote at least two posts in the collective blog, (30 of such collective blogs were created in blogspot.com environment). 132 of the sample were student teachers and 111 were NQT. The data was gathered from 1900 blog posts which were divided into 3001 segments (unit of the analysis consisting of one topic or idea and which is comprehensible by itself). The researchers from the research team encoded the blog posts independently, and in the case of a discrepancy it was discussed until agreement was reached. The Chi-square test, Wilcoxon test and Mann-Whitney U-test were used for data analysis.

\section{Results and discussion}

Teaching, management of practice, and students were the three prevailing topics in the ST' blogs. These three topics dominated in all periods of practice. This result is in line with previous studies (e.g. Rettig, 2013). In the case of NQT posts teaching prevailed in all periods, but the importance of other topics increased and decreased depending on the period. One of the reasons for that may be the fact that the duration of the induction year (almost all academic year) is longer than the duration of practice (7-12 weeks) and, therefore, different issues might dominate in different periods. 
There were four statistically significant differences in the proportion of topics of posts between those two groups (ST' and NQT'): blog, parents, colleagues and management of practice/induction year. All of these topics were proportionally larger in NQT' blogs. Surprisingly few topics addressed learning. It was an interesting result, because both teaching practice and the induction year are the stages of the teacher education and learning that are important in these stages. Also, the previous studies (e.g. Fisher \& Kim, 2013) have claimed that reflecting on one's own posts helps to make learning more visible to them and ST also discuss the concord of theory and practice. However, our results did not support this. Maybe mentors should guide ST and NQT to discussions about learning from experiences.

ST posted more about their success compared to the NQT, but in both groups topics with neutral content prevailed. While in the case of ST the proportion of the posts about success was larger than the posts about problems in all periods, it was the same only in the first and last periods in the case of NQT. Merrill (2006) also claims that NQT need a possibility to share concerns and maybe the blog environment is one of the possibilities to do that. It may also refer to the fact that the ST have more support, compared to the NQT.

ST wrote about blogs, learning, teaching, management of practice and colleagues as successful experiences more than as problematic experiences. NQT wrote about the management of practice more as successful experiences, but about students more as problematic experiences. The previous studies (e.g. Eisenschmidt, 2006b; Haggarty et al., 2011) have also pointed out that the behaviour of students is one of the problematic issues in the case of NQT.

Appearance of the teachers' professional development in posts was analysed, using Fuller and Bown's (1975) model of concerns. All of the four stages (pre-teaching concerns, survival, teaching, and students) appeared in the posts of both groups, despite Fuller and Bown (1975) claim that the first stage is more common in the case of the ST. The first stage disappeared in the posts of NQT after the third period. The most prevalent stage in the posts of both groups was the survival stage which was quite an expected result, because the worries of how I manage with the class is one of the most burning topics during the teaching practice (e.g. Fisher \& Kim, 2013; Ozdemir \& Yildirim, 2012; Rettig, 2013) and during the induction year (Eisenschmidt, 2006c). It was quite interesting that the proportion of the survival stage was larger in NQT' blogs compared to the ST blogs. It might be that ST who have more support from supervisors of universities and 
practice schools, do not realise all the demands of the teachers' work. NQT have to bear responsibilities of educating students.

Being aware of the experiences and concerns of ST and NQT might give an important input to teacher education - it gives the possibility to organise teaching practice and the induction year and to support ST and NQT. It is important that novice teachers do not confront only with concerns, but sustain also success and satisfaction. The results of our study might be used for that input.

Keywords: teaching practice, induction year, blog, professional development of teachers 